\title{
Arte y política: un estudio comparativo de Jacques Rancière y Nelly Richard para el arte latinoamericano*
}

\author{
Verónica Capasso* \\ Ana Bugnone $e^{* * *}$
}

Recibido: 25 de noviembre 2015

Evaluado: 29 de febrero de 2016

Aceptado: 14 de marzo de 2016

\section{Resumen}

En este artículo se indagan y comparan las teorías de Jacques Rancière y Nelly Richard sobre la relación entre arte y política desde el pensamiento posfundacional, y se producen reflexiones y análisis de manifestaciones artísticas latinoamericanas vanguardistas o críticas en diálogo con ambas. Para ello, se parte de una presentación de las teorías de Rancière y Richard en términos generales, se focaliza en las ideas que dichos autores tienen de la política y, específicamente, en la conceptualización que hacen del arte y su relación con la política. Al mismo tiempo, se desarrolla una interpretación de producciones artísticas desde una mirada centrada en sus diversas conexiones con lo político, más allá del contenido temático de estas. Se utiliza la perspectiva metodológica cualitativa transdisciplinaria, que articula distintas áreas de conocimiento (filosofía política, sociología, historia

\footnotetext{
Artículo de investigación. Proviene de la labor realizada en el marco de la línea de investigación Arte, estética y política, perteneciente al Área de Estudios Políticos Latinoamericanos de la Facultad de Humanidades y Ciencias de la Educación, Instituto de Investigaciones en Humanidades y Ciencias Sociales, Universidad Nacional de La Plata-Consejo Nacional de Investigaciones Científicas y Técnicas (Conicet). Cómo citar este artículo: Capasso, V. y Bugnone, A. (2016). Arte y política: un estudio comparativo de Jacques Rancière y Nelly Richard para el arte latinoamericano. Hallazgos, 13(26), 117-148 (doi: http://dx.doi.org/10.15332/s1794-3841.2016.0026.05).

** Magíster en Ciencias Sociales, doctoranda en Ciencias Sociales. Investigadora en el Instituto de Historia del arte argentino y americano, Facultad de Bellas Artes, Universidad Nacional de La Plata y en el Instituto de Investigaciones en Humanidades y Ciencias Sociales, Facultad de Humanidades y Ciencias de la Educación, Universidad Nacional de La Plata. Becaria doctoral tipo A, UNLP. Correo electrónico: capasso.veronica@gmail.com. Calle 8 entre 59 y 60, nro. 1326, Primer Piso, La Plata, CP (1900), Provincia de Buenos Aires, Argentina.

*** Doctora en Ciencias Sociales. Investigadora en el Instituto de Investigaciones en Humanidades y Ciencias Sociales, Facultad de Humanidades y Ciencias de la Educación, Universidad Nacional de La Plata - Consejo Nacional de Investigaciones Científicas y Técnicas (Conicet). Correo electrónico: anabugnone@gmail.com. Calle 51 entre 124 y 125, Edificio C, aula C304, Ensenada. CP (1925), Provincia de Buenos Aires, Argentina.
} 
del arte). En el caso de los desarrollos de Jacques Rancière, se recurre a herramientas teóricas metropolitanas para resituarlas y repensarlas en función del arte de Latinoamérica. En este sentido, se trata de potenciar sus ideas en el análisis de casos locales. En cuanto a la teoría de Nelly Richard, sus conceptos de arte crítico y vanguardista se ponen en relación con el arte latinoamericano. Finalmente, se propone una comparación en la cual se destacan similitudes y diferencias conceptuales entre ambos en combinación con análisis de casos para abrir el panorama analítico e interpretativo que vincule teorías actuales con estudios de manifestaciones artísticas locales.

Palabras clave: arte, política, Jacques Rancière, Nelly Richard, arte latinoamericano. 


\section{Art and politics: a comparative study of Jacques Rancière and Nelly Richard for Latin American art}

Received: November 25, 2015

Evaluated: February 29, 2016 Accepted: March 14, 2016

\section{Abstract}

This paper explores and compares Jacques Rancière's and Nelly Richard's theories on the relationship between art and politics from the perspective of post-foundational thought. We reflect and analyze avant-garde or critical artistic expressions from Latin America in dialogue with both theories. Therefore, we first provide an overview of Rancière's and Richard's theories, focusing on the ideas that these authors have about politics and, specifically, their conceptualization of art and its relationship to politics. We also make an interpretation of artistic productions centered on their several connections with the political, regardless of their thematic content. We use the qualitative methodology with a transdiciplinary perspective, which articulates different fields of knowledge (philosophy, politics, sociology, art history). In the case of Jacques Rancière, we draw on metropolitan theoretical tools in order to relocate and rethink his developments in relation to Latin American art. In this regard, our discussion aims at enriching his ideas in the analysis of local cases. As for Nelly Richard, we link her concepts of critical and avant-garde art with Latin American art. Finally, we put forward a comparison where conceptual similarities and differences between Rancière and Richard are highlighted along with the analysis of cases so as to widen the analytical and interpretative framework combining present theories with studies of local artistic expressions.

Keywords: Art, politics, Jacques Rancière, Nelly Richard, Latin American art. 


\section{Arte e política: um estudo comparativo de Jacques Rancière e Nelly Richard para a arte latino-americana}

\section{RESUMO}

Neste artigo indaga-se e comparam as teorias de Jacques Rancière e Recebido: 25 de novembro de 2015 Nelly Richard sobre a relação entre arte e política desde o pensamento pós-fundacional e se produzem reflexões e análises das manifestações artísticas latino-americanas vanguardistas ou críticas em dialogo com ambas. Por isso, se parte de uma apresentação das teorias de Rancière e Richard em termos gerais foca-se nas ideias que estes autores têm sobre a política e, especificamente, na conceptualização que fazem da arte e sua relação com a política. Ao mesmo tempo, desenvolve-se uma interpretação de produções artísticas desde uma olhada focada em suas diversas conexões com a política, além do conteúdo temático de estas. Utiliza-se a perspectiva metodológica qualitativa transdisciplinar, que articula distintas áreas do conhecimento (filosofia, politica, sociologia, história da arte). No caso dos desenvolvimentos de Jacques Rancière, se recorre a ferramentas teóricas metropolitanas para situá-las e repensá-las em função da arte latino-americana. Neste sentido, trata-se de potenciar suas ideias na análise de casos locais. No relacionado com a teoria de Nelly Richard, seus conceitos da arte crítica e vanguardista se relacionam com a arte latino-americana. Finalmente, se propõe uma comparação na qual se destacam similitudes e diferenças conceptuais entre ambos, em combinação com análise de casos para abrir o panorama analítico e interpretativo que vincule teorias atuais com estudos de manifestações artísticas locais.

Palavras-chave: arte, politica, Jacques Rancière, Nelly Richard, arte latino-americana.

Avaliado: 29 de fevereiro de 2016

Aceito: 14 de março de 2016 


\section{INTRODUCCIÓN}

Desde los estudios sociales del arte se ha abordado la relación entre arte y política de diversas maneras, predominando la lectura que reduce la politicidad al contenido o el mensaje de una obra artística. Desde otra perspectiva, este artículo ${ }^{1}$ se propone indagar las teorías de Jacques Rancière y Nelly Richard sobre la relación entre arte y política desde el pensamiento posfundacional ${ }^{2}$ $\mathrm{y}$ vincularlas con algunas manifestaciones artísticas latinoamericanas de carácter vanguardista, en algunos casos, y críticas del statu quo social y político, en otros. ${ }^{3}$ Así, este trabajo se justifica, por un lado, porque expone las teorías de Rancière y Richard desde el punto de vista específico de los modos

1 Un borrador del trabajo sobre la teoría de Rancière fue presentado por Ana Bugnone con el título "Algunos conceptos para pensar la política y lo politico en el arte" en las Primeras Jornadas de Estudios Políticos Latinoamericanos, Facultad de Humanidades y Ciencias de la Educación, de la Universidad nacional de La Plata (unLP), 5 y 6 de junio de 2014. Asimismo, este artículo proviene de la tesis de maestría de Verónica Capasso (2015), que realiza una comparación entre las teorías de Jacques Rancière, Chantal Mouffe y Nelly Richard.

2 En El pensamiento político posfundacional, Oliver Marchart (2009) define como posfundacionales los proyectos teóricos de una selección de autores, diferenciándolos de posturas dogmáticas (fundacionalistas) y posmodernas (antifundacionales). Brevemente, el pensamiento posfundacional supone dos cuestiones entrelazadas:por un lado, el uso de las figuras de la contingencia, es decir, que toda sociedad ha sido fundada, instituida y que puede ser refundada una y otra vez. De esta manera, el pensamiento político posfundacional se caracteriza por la ausencia de fundamentos trascendentales ahistóricos. Esto no es ausencia sino debilitamiento del estatuto ontológico del fundamento, siendo este efímero, contingente y parcial. Por otro lado, este pensamiento está caracterizado por el empleo de la diferencia política, la cual supone una diferenciación entre el plano ontológico -como la forma de institución y desinstitución del orden-y el plano óntico —el sistema político o formas institucionales que produce una comunidad para tramitar sus conflictos-. Esto da cuenta de la negatividad e imposibilidad de un fundamento último, como así también su institución parcial.

3 A excepción del caso de la cerámica moche, cuyas características son explicadas en el apartado 1.2. como relacionan arte y política, ${ }^{4} \mathrm{y}$ presenta un análisis comparativo entre ambos autores sobre estos temas, investigación novedosa en el campo de los estudios sociales del arte. Por otro lado, porque el análisis que realiza de las manifestaciones artísticas latinoamericanas, además de estar circunscriptas al recorte mencionado (vanguardistas o críticas), desarrolla una interpretación que centra la mirada en sus diversas conexiones con lo político, más allá del contenido temático de estas. Este trabajo se diferencia, entonces, de la mirada usual con la que ha sido vista la conexión entre arte y política en Latinoamérica.

Partiendo de la importancia que tienen las teorías de Richard y Rancière en la actualidad, realizaremos una presentación somera, pero necesaria, de ambas para centrarnos luego en la relación que proponen entre arte y política; produciremos, además, un análisis comparativo a la par que generaremos reflexiones y análisis de manifestaciones artísticas de Latinoamérica. ${ }^{5}$ Para ello, utilizaremos la perspectiva metodológica cualitativa transdisciplinaria (Richard, 2014) que articula distintas áreas del conocimiento (filosofía política, sociología, historia del arte) y permite producir una mirada analítica e interpretativa que amplíe el panorama actual de las investigaciones sociales del arte.

En el caso de los desarrollos de Jacques Rancière, proponemos recurrir a herramientas

4 Por razones de espacio, no avanzaremos en profundidad sobre los aspectos generales de las teorías de Richard y Rancière, que ya han sido abordados por otros autores latinoamericanos, a los que remitimos para su lectura. Cfr.Guerra (2005), Arcos Palma (2009), Yepes Muñoz (2010), Di Filippo (2011), Lazzara (2013).

5 Todas las imágenes reproducidas en este artículo son utilizadas con fines exclusivamente académicos y no comerciales. Se cita en cada caso la fuente de la que fueron extraídas. 
teóricas metropolitanas para resituarlas y repensarlas en función del arte latinoamericano. En este sentido, se trata de potenciar su propuesta en el análisis de casos locales y "situados". ${ }^{6}$ En cuanto a la teoría de Nelly Richard, son conocidos los estudios que ha realizado sobre el arte chileno, por lo que la conexión entre las teorizaciones que produjo y el arte local es directa.

Cuando nos preguntamos de qué modo pueden relacionarse arte y política, resuena el discurso moderno que vincula ambos términos por una cercanía temática, es decir, por una obra cuyo tema es político o por el grado de "compromiso" asumido por su autor con la realidad social. Se supone así que arte y política son esferas institucionalmente diferenciadas y reconocidas. Por ello, para que el arte sea político, debería intervenir en esa otra esfera, que es la de la política. Se trataría, entonces, de que el arte incorpore el discurso de la política, sus representaciones, estrategias, enunciados, su definición de amigos y enemigos.

Esta posición, si bien fue hegemónica, ha sido criticada desde diversos puntos de vista. Así, Richard (2005) afirma que es posible distinguir entre dos formas de vinculación entre arte y política. La primera, mencionada arriba, es pensar en "arte y política" como dos esferas separadas, en la que el arte sería un subconjunto de la esfera cultural, y la política, una totalidad histórico-social que da un contenido al arte, el cual debe tematizarla. La segunda se trata de pensar "lo político en el arte" que rechaza

6 Según Nelly Richard, "Io 'situado' sirve para realzar la especificidad creativa de las operaciones de resignificación y dislocación de los signos que marca la experimentalidad artística en América Latina con toda la carga irruptiva y disruptiva que conlleva" (citada en Quezada, 2014). la correspondencia establecida de antemano entre ambos términos y se refiere a una articulación interna a la obra que, desde sus propios medios y organización simbólica, reflexiona críticamente sobre lo social. La teoría de Rancière sobre la estética también ha renovado la mirada moderna sobre la relación entre arte y política. Lejos de plantear un abandono postmoderno de la potencialidad política del arte o de pensar todo arte como político, plantea que esa relación sigue viva, aunque en unos modos y condiciones específicos.

El filósofo francés se ha caracterizado como otros - por intentar disolver los planteos dicotómicos y simplificados. Así, las oposiciones modernidad/postmodernidad, universalidad/particularismo, arte (autónomo)/política no son, para él, productivas y ha propuesto para cada una de ellas un desarrollo conceptual más complejo. Asimismo, ha intentado evitar la afirmación de que la cultura y el arte en particular son construcciones que (solo) contribuyen a la reproducción del orden social. En el mismo sentido, Richard ha abogado por el descentramiento frente a ciertos binarismos: centro/periferia, masculino/femenino, dominación/ subordinación, en el marco del desarrollo de una práctica crítica que denominó crítica cultural, la cual, además, pone el locus en la especificidad de la materialidad estética, lo marginal y extrainstitucional, el carácter transdisciplinario y las políticas identitarias no esencialistas. En cuanto al arte, ha planteado el rol dislocatorio que puede tener en términos perceptivos e intelectivos.

A partir de la exposición de las propuestas de Jacques Rancière y Nelly Richard que se desarrollará a lo largo de este artículo, es posible encontrar similitudes entre ambos. 
Se repondrá, en cada caso, la perspectiva teórico-política y en ese marco la concepción del arte y del arte político/crítico. Posteriormente, se establecerán nexos entre los autores en torno al rol de la obra política, el espectador y el artista en estrecha vinculación con casos latinoamericanos.

\section{JACQUES RANCIÈRE: LA POLÍTICA, LA ESTÉTICA Y EL REPARTO DE LO SENSIBLE}

\section{La política como disenso}

Para comenzar, parece necesario introducir la concepción que tiene Rancière de la política, ya que reviste un carácter especial. El trabajo en el que acuña este concepto de un modo más consistente es en El desacuerdo: política y filosofía (2007a). Allí parte de una diferenciación básica: policía y política. Policía es el orden social naturalizado, que supone un ordenamiento de sujetos y objetos, lugares, disposiciones y jerarquías, lo cual permite que unos sean visibles y otros no, que unos tengan voz y otros emitan ruido. Este orden es, por ello, una organización del régimen de sensibilidad que ubica cuerpos, capacidades, ocupaciones, modos de ser, de hacer y de decir de acuerdo con reglas impuestas socialmente. Implica también un consenso en relación con su funcionamiento y permite que diferentes sujetos, de acuerdo con la posición que ocupan, puedan hacerse visibles o sean ignorados como tales. En cuanto a estos últimos, pueden en ciertas ocasiones salir del lugar al que han sido reducidos o destinados, emerger al mundo de los socialmente parlantes y distorsionar, de este modo, el orden policial. Así sucede cuando aparece la política: una ruptura del orden de la dominación, lo que significa un necesario reacomodamiento de los lugares que ocupa cada uno y de lo que está permitido en términos de habla, goce, visibilidad pública, capacidad de disposición. Para Rancière, "la esencia de la política es el disenso. El disenso no es la confrontación de intereses $\mathrm{u}$ opiniones. Es la manifestación de una separación de lo sensible consigo mismo" (2006c, p. 73). Esto significa que el disenso supone una reconfiguración del orden que determina que no hay lugar para los que no tienen parte, es decir, que impone la negación de la política, la supresión de la igualdad. ${ }^{7}$ En este sentido, dice Rancière:

Sólo hay política cuando esas maquinarias [el ejercicio de la majestad, el vicariato de la divinidad, la gestión de intereses] son interrumpidas por el efecto de un supuesto que les es completamente ajeno y sin el cual, sin embargo, en última instancia ninguna de ellas podría funcionar: el supuesto de la igualdad de cualquiera con cualquiera, esto es, en definitiva, la eficacia paradójica de la contingencia de todo orden. (2007a, p. 32)

De este modo, en el momento de verificación de la igualdad se produce un choque entre dos procesos heterogéneos: el de la policía y el de la emancipación. Se hace evidente que todo orden es contingente, construido, no natural, es decir, una ficción, por lo que la política viene a distorsionar una permanencia aparentemente inmutable $\mathrm{y}$ a poner en evidencia que hay un escenario común: la existencia de una comunidad. Pero la política no existe por sí misma, no tiene objetos propios, sino que está siempre

7 Para profundizar sobre la política, el disenso y la democracia, ver Rancière (2006c). 
enlazada a un orden policial específico, que pone en cuestión y que opone a la lógica policial la lógica igualitaria.

La política se vincula también con la subjetivación porque aparecen en el ámbito de la experiencia y la representación aquellos que no tenían lugar y no eran contados en el orden policial. Esto rompe su lógica y posibilita la emergencia de nuevos sujetos de enunciación; por lo tanto, visibles y con capacidad de hacer y decir. Es por ello que para Rancière la subjetivación es una des-identificación: una modificación de las capacidades y propiedades de los que estaban identificados en una cierta jerarquía del orden policial.

\section{De la POLÍtica a la estética Y LOS TRES REGÍMENES DE IDENTIFICACIÓN}

Nos preguntamos ahora qué lugar ocupa el arte en esta teoría y por qué Rancière ha vinculado la estética con la política. Para este filósofo la estética no está relacionada con la percepción de lo bello ni con la idea de estetización de la política de Walter Benjamin (1989). La estética es para Rancière al menos dos cosas: es una de las formas (la otra es la política) que produce una reconfiguración de los datos sensibles a partir del disenso, una experiencia sensorial específica que ofrece nuevas configuraciones del espacio (2002b); además, es un régimen histórico de identificación del arte que se inició entre fines del siglo XVIII y principios del XIX (2006b). En este régimen las obras de arte se identifican por su pertenencia a un espacio común y no por el uso de técnicas específicas.

Rancière sostiene que hay una estética de la política que reconfigura la división de lo sensible: el efecto que produce la política o, mejor dicho, el encuentro entre la política y la policía en la partición de espacios y tiempos, lugares, identidades, lo visible y lo invisible, el lenguaje y el ruido. Hay también una política de la estética: los modos como las prácticas y visibilidad del arte reconfiguran lo sensible, interviniendo en su división y así en las coordenadas de la experiencia sensorial (2005). La relación entre ambas (la estética de la política y la política de la estética) explica el modo como se vinculan arte y política: estos entran en relación porque ambos dependen de un cierto régimen de identificación. Para que esto ocurra, según Rancière, el arte mantiene su autonomía como tal - cuestión que veremos más adelante- y es desde su producción específica que se cruza con la política en la reconfiguración de lo sensible.

¿En qué contextos se dan estas relaciones? ¿Qué es considerado arte en cada contexto y cómo se relaciona con lo social? Para responder estas preguntas es necesario recurrir a otro concepto. Un régimen de identificación del arte define qué es y qué no es arte. Es "un régimen de percepción $\mathrm{y}$ de pensamiento que permita distinguir sus formas [del arte] como formas comunes [...]. Pone determinadas prácticas en relación con formas de visibilidad y modos de inteligibilidad específicos" (Rancière, 2005, p.18). Rancière dice que estos regímenes son históricos, es decir, que el arte o la literatura aparecen como tales en el momento en el que son reconocidos como maneras de hacer con una visibilidad y forma de inteligibilidad nuevas. La diferenciación de regímenes no implica que entre uno y otro haya una ruptura, un pasaje rotundo entre un tipo de arte y otro en un momento histórico 
determinado, sino distintos funcionamientos o lógicas que son históricos, pero cuyos elementos pueden pertenecer a épocas diferentes. Por ello, podemos encontrar ejemplos de cada uno en múltiples temporalidades y hasta en modalidades anacrónicas (Rancière, 2006a).

Rancière reconoce tres regímenes de identificación. Para el primero, el de representación mimética, el arte es una imitación, una apariencia verosímil y allí se considera que una obra de arte representa una intención del autor, que transmite un mensaje que es captado claramente por el público y que lleva, por ende, a un tipo de acción determinada. Hay una continuidad que va del autor a la obra, y de allí a la comunidad. De este modo, mantiene una intencionalidad pedagógica hacia quienes lo reciben. Podemos ver que este régimen se pone en funcionamiento en el caso de las obras del personaje Juanito Laguna del artista argentino Antonio Berni (1905-1981). Berni ideó una serie de collages y grabados sobre este personaje arquetípico que representa a un niño que vive en las villas miserias argentinas y en él simboliza también a toda la pobreza latinoamericana (imagen 1). En los collages, el artista utilizaba material de descarte, cartones, chapas, textiles recuperados de la basura, y los incorporaba para mostrar los elementos que formaban parte de las condiciones de vida del niño. Así, lo mimético no solo está dado en la factura de una figura humana verosímil, sino en la propia materialidad que parece llevar el deseo de representación realista a su máxima expresión. Berni, que había pertenecido al partido comunista, quería no solo mostrar la realidad de la pobreza argentina, sino también concientizar a los espectadores. En palabras de Berni, Juanito implicaba "registrar la realidad viva y característica de los países subdesarrollados, y [...] testimoniar sobre la terrible apropiación del neocolonialismo, con la pobreza y el retardo económico (Berni, citado en Burucúa, 1999, pp. 96 y 97). De este modo, en el régimen mimético el arte funcionaría como un dispositivo pedagógico a través de obras que podrían generar un sentimiento de proximidad y transmitir un mensaje propuesto por el artista que llegaría intacto al público. Se espera, además, que la obra genere un impacto que lleve a la acción del espectador $y$, en consecuencia, a la intervención política.

Imagen 1. Antonio Berni, Juanito va a la ciudad (1963)

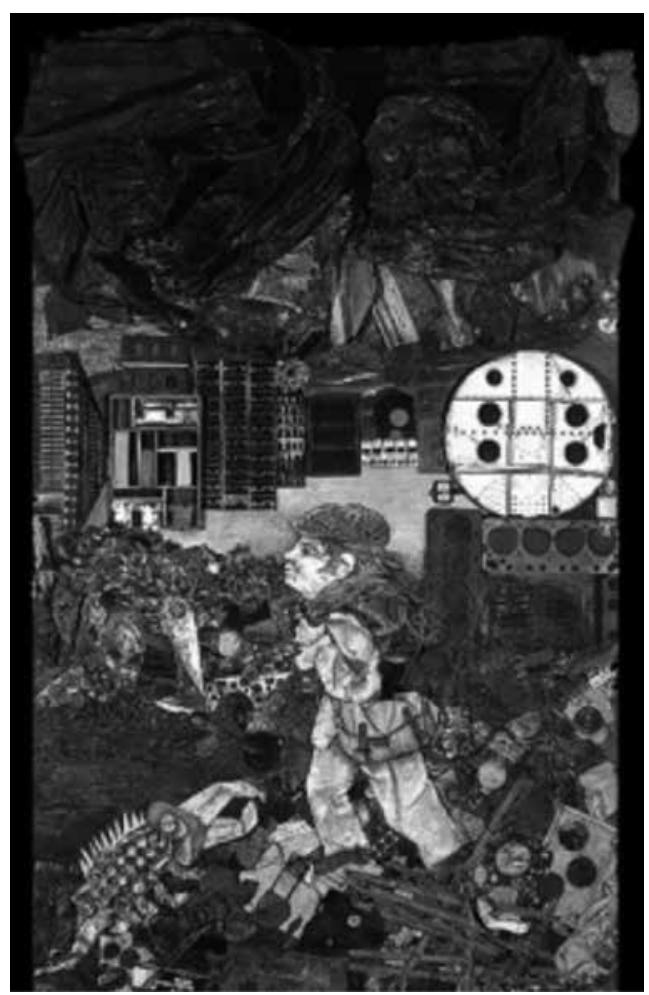

Fuente: The Museum of Fine Arts Houston. 
Rancière sostiene que frente a este se propone otro régimen llamado Archiético o Ético, en el que las imágenes se juzgan en función de sus efectos sobre el modo de ser de los individuos y la colectividad. Consiste en la disolución del arte, que se convierte en la comunidad en acto. En este proyecto, el arte se transforma en una forma de vida, suprimiendo su singularidad, su heterogeneidad sensible (Rancière, 2005). Ya no hay separación entre el arte y la vida, porque el arte ha traspasado sus barreras para incorporarse directamente a ella. De este modo, no existe arte propiamente dicho sino imágenes (Rancière, 2011) que producen determinada significación.

Dentro de este régimen podemos ubicar a las producciones religiosas o aquellas utilizadas en contextos rituales, donde una escultura o una pintura son aprehendidas como imágenes de la divinidad en un espacio de encuentro comunal. Pertenece a la lógica de este régimen la cerámica moche (imagen 2), cultura prehispánica del antiguo Perú, que se desarrolló entre el año 100 y el 700 d. C. en el valle del río Moche. En ella la cultura moche representó, tanto de manera escultórica como pictórica, a divinidades, hombres, animales y escenas significativas referidas a temas ceremoniales, rituales y mitos que daban cuenta de su concepción del mundo. Asimismo, realizaron cerámica con imágenes más abstractas y conceptuales, así como con representaciones sexuales y eróticas. Estas producciones eran utilizadas en contextos cotidianos y domésticos, en su vida espiritual y como ofrenda para los muertos. De esta forma, la cerámica materializaba una experiencia colectiva. Si bien hoy podemos analizar estas cerámicas como producciones artísticas, entendemos
Imagen 2. Cerámica moche (entre 100 y 700 a. C.)

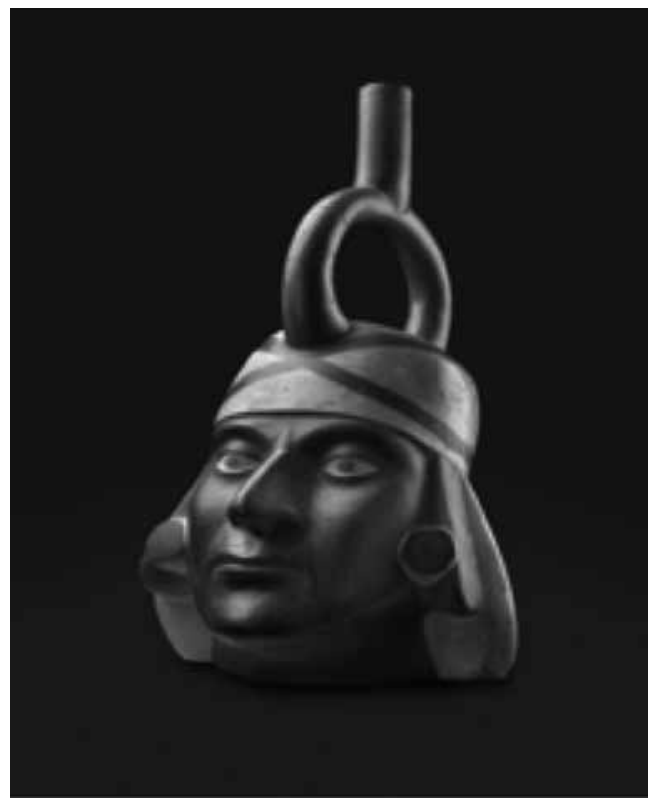

Fuente: Museo Nacional de Antropología e Historia, Lima.

que estas prácticas son de carácter antropológico, dado que forman parte de la vida cultural de los pueblos que las ejecutan y, por lo tanto, más que artísticas, aparecen como sociales.

Finalmente, en el Régimen estético el arte se define por su pertenencia a un sensorium específico, es decir, se trata de una forma sensible heterogénea que se opone a las de la experiencia ordinaria $\mathrm{y}$, por lo tanto, al orden policial. Se vincula con una nueva forma de comunidad (y de ahí su politicidad) porque define al arte en función de su relación con una sensibilidad diferente a la de la dominación (Rancière, 2006b, 2010a). Se impone una separación entre las formas del arte y las formas por las cuales es aprehendido por el público. Aquí no hay un mensaje, sino una distancia respecto de lo 
que el arte debe transmitir hacia la comunidad, por eso se trata de una disyunción o una separación. En este sentido, se configura como disruptivo y pone en juego un espacio y una temporalidad diferentes de las que constituyen la normalidad del orden social. Así, la temporalidad propia de este régimen es la de una copresencia de temporalidades heterogéneas. En este régimen, opera una experiencia estética que transmuta el orden social, y de esta manera trastoca la división de lo sensible, pero desde su propia especificidad artística, sin fundirse en la comunidad. Ahí se encuentra su potencia: es necesaria esa separación estética que libra al arte de todo deber particular. Para ello, Rancière toma la frase de Adorno que sostiene que "la función social del arte consiste en no tener ninguna": aquí una obra "no pretende nada" (Rancière, 2005, p. 29) y es igualitaria por cuanto niega toda preferencia y toda jerarquía asimilable al sensorium de la vida cotidiana.

Uno de los momentos en que se configuró una forma sensible heterogénea en el marco de régimen estético ocurrió cuando un colectivo de artistas realizó una performance vinculada con la peor inundación sufrida en la La Plata (Buenos Aires) en las últimas décadas. Después de la catástrofe que dejó decenas de muertos y heridos, se produjo una serie de respuestas ciudadanas cuestionando la desidia del Gobierno local, entre ellas, las artísticas. El grupo La marca del agua interrumpió el curso normal de la Feria del Libro organizada por la Municipalidad de La Plata, dos meses después de la inundación (imagen 3). Frente a la mirada sorprendida de feriantes, compradores y organizadores, el grupo repitió varias veces una poesía que a la vez que describía el desastre natural, denunciaba el tratamiento que se hacía sobre el hecho desde el municipio y los medios de comunicación. “Desde la puñalada de la espalda, nos queda esta intemperie desmedida, de galopar de la crónica perfecta, la misma que los noticieros desafían, en su banquete diario de perversión y especuladora miseria" (La marca de agua, 2013, s. p.), es parte de la poesía gritada entre el ruido de la Feria del Libro. Como sostiene una de las integrantes del grupo, se organizaron frente a la invisibilización del desastre que se producía desde las instituciones locales. La forma de pensar la acción poética estuvo relacionada con intervenir en un espacio público normalizado, mostrando la ausencia de acciones efectivas orientadas a resolver la situación de la población afectada y también de los negocios y políticas urbanísticas que eran parte causal de la inundación: "el paro cardíaco de la inoperancia: mamá política no puede con la naturaleza pero su obligación es amamantar a todos sus bebés" (La marca de agua, 2013, s. p.). Como podemos observar, la operación literaria es doble, mostrar lo que la política debería hacer (dar cuenta de todos los miembros de la comunidad), pero señalando su ineficacia. Esto se acerca a lo que Rancière llama el tratamiento del daño y a la heterología de las palabras y el ruido, se le agrega la de las prácticas que interrumpen el curso normal de la policía. La poesía fue recitada varias veces desde diferentes lugares en el espacio de la Feria del Libro y rompía con la regla de no hablar de política, de la inundación, ni del intendente, mientras en el lugar se subía el volumen de la música para que no fuesen escuchados.

Es importante señalar que para Rancière los tres regímenes antes expuestos representan 
Imagen 3. La marca del agua, Episodio 1 (2013)

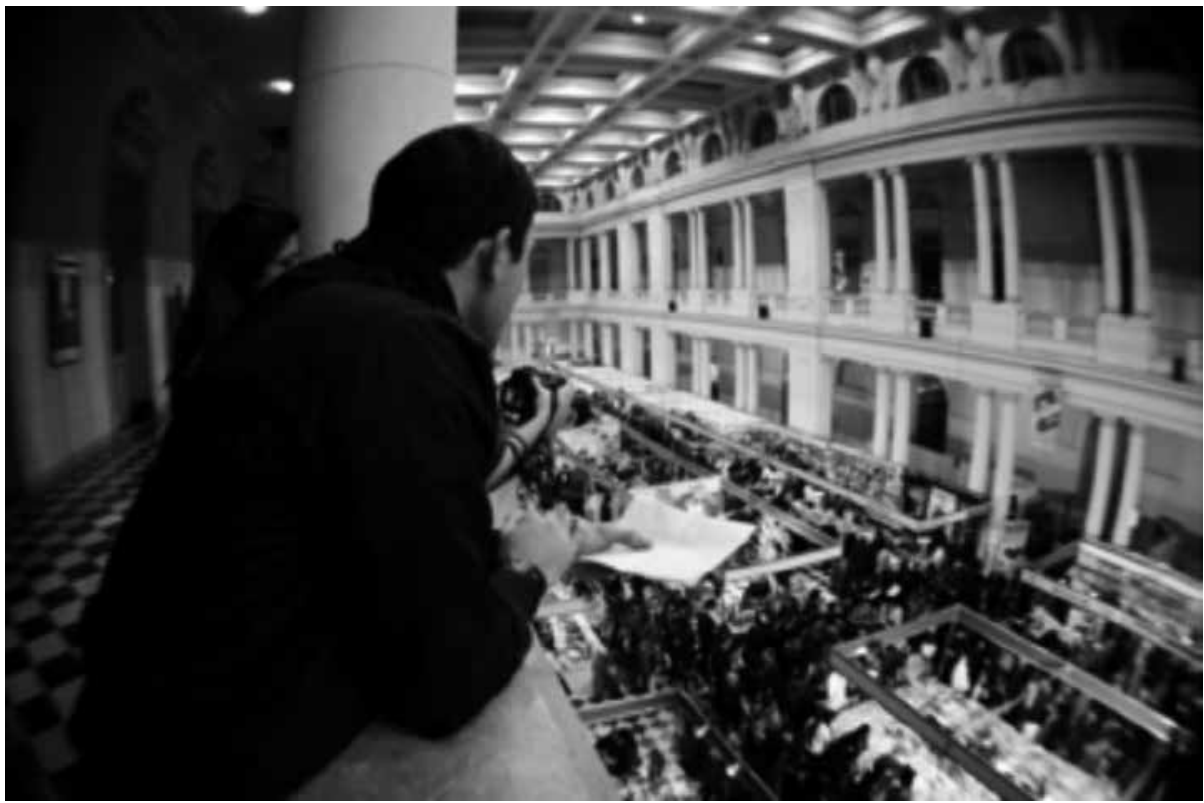

Fuente: La marca del agua, La Plata.

lógicas que funcionan entrelazadas cuando se vinculan arte y política. Así, no son dos esferas antagónicas, sino que arte y política confluyen en que producen efectos semejantes sobre la partición de lo sensible. El arte no genera un nosotros como lo hace la política, sino que permite la experiencia estética que, como ficción, se encuentra con otra ficción - la del orden social - para distorsionarla, lo que hace evidente su carácter ficcional y no de realidad. En relación con esto, Rancière (2007b), desde la perspectiva posfundacional, dice que:

[La ficción] es el trabajo de redistribución de las relaciones entre las cosas, las imágenes y las palabras. Es una manera de cambiar los modos de representación sensible, de variar los marcos, las escalas y las velocidades de manera que se produzcan una nueva configuración de lo que es perceptible, decible y posible en un mundo común, una manera pues de cambiar la distribución de las 'competencias'. (s. p). ${ }^{8}$

Así, más que generar directamente subjetividades políticas, el arte en el régimen estético perturba la distribución de lo sensible que jerarquiza e identifica los espacios, la ubicación de los cuerpos y establece los modos de decir, hacer y ser visible correspondientes a cada parte. Este encuentro o "choque de

8 Citamos aquí la primera edición de "Estética y política: las paradojas del arte político", publicada en 2007 en Internet (sin números de página), dado que en la versión más reciente (Rancière, 2010), si bien se conserva lo sustancial del texto, se han modificado o suprimido partes que conectaban ideas de un modo más claro y explicativo. 
dos regímenes de sensorialidad" (Rancière, 2007b, s. p.) es el disenso e implica una colisión entre el sensorium policial y la política, por cuanto-en esos casos - el arte cuestiona y reconfigura los lugares asignados a los cuerpos, las funciones y la competencias sociales, "construyendo nuevas relaciones entre la apariencia y la realidad, lo singular y lo común, lo visible y su significado" (Rancière, 2007b, s. p). Si el orden policial es, antes que nada, una representación de la división de lo sensible, el arte puede operar sobre ella, oponiendo a esa ficción otra ficción, es decir, otra construcción de espacio (Rancière, 2010a) y tiempo (Rancière, 2010b) que crea disensos. Sin embargo, el disenso generado por la oposición entre ficciones, implica una indeterminación, puesto que no pueden calcularse los efectos que ejercerá el arte sobre los sujetos, tanto porque produce una distancia estética como porque no puede establecerse previamente una correspondencia entre la reconfiguración de lo sensible y la creación de colectivos o acciones políticas.

Por ello, la relación entre el arte y la política es entre dos ficciones, dos representaciones de lo sensible y sus particiones que se enfrentan con la ficción dominante, la del orden social. El hecho de que ese orden sea dominante explica que aparezca como "natural". Esto se vincula, además, con la idea de que la policía, que opera en ese orden, convierte a las técnicas de gobernar en "leyes naturales" (Rancière, 2000); sin embargo, a pesar de esa apariencia, no es lo real, sino solo una ficción a la cual se le oponen otras. Así, el arte y la política pueden hacer ver lo que no era visto o hacer escuchar como discurso lo que estaba destinado a ser ruido, en definitiva, repartir lo sensible de un modo distinto al de ese orden dominante.

\section{Autonomía, heteronomía Y "TERCERA VÍA"}

Como vimos, si bien Rancière rechaza la oposición simple entre arte y política, no descarta la existencia de un tipo de autonomía particular. A pesar de que podría confundirse con la concepción modernista, el autor ha planteado la autonomía del arte de un modo diferente, poniendo en el centro la tensión que hay en su interior.

En términos generales, la problemática de la autonomía del arte refiere a dos cuestiones: la existencia de una esfera autónoma, con criterios y reglas propios, y el supuesto derrumbe de esa autonomía a fines del siglo $x x$, producido por la caída de los límites que la separan del resto del mundo social. Rancière intenta dar por tierra la oposición entre autonomía y heteronomía del arte, así como la dicotomía entre arte moderno y postmoderno. Su propuesta supone los amplios debates que han surgido al respecto, así como el fuerte cuestionamiento que se ha realizado a la noción de autonomía del arte, vinculado originalmente con la idea de "arte por el arte", es decir, un arte ajeno al mundo social, libre de condicionamientos y dedicado exclusivamente a la creación. Las propuestas de fusionar arte y vida de las vanguardias históricas y de los artistas que planteaban un compromiso social en los años sesenta pusieron en jaque esa diferenciación tajante. Frente a esto, y retomando parte de la teoría adorniana, Rancière se propone rescatar la idea de autonomía del arte, pero tensionándola y combinándola con su opuesta, la heteronomía.

En primer lugar, interesa destacar que para Rancière la esfera de la estética es autónoma por cuanto está separada de otras, pero allí 
se producen obras de arte que, por el contrario, son heterónomas: sus objetos no pueden distinguirse de los de las otras esferas. Para Rancière, este encuentro de autonomía y heteronomía define el lugar de la política de la estética. Es por ello que no hay oposición entre arte y política, o entre "la pureza del arte y su politización" (Rancière, 2005, p. 23). El conflicto está en el seno de su pureza, es decir, en el arte como forma de experiencia autónoma. Es desde este lugar que el arte puede instituir nuevas divisiones de lo sensible, justamente porque se propone como una reconfiguración de las formas habituales de esa partición y su representación. Esto es lo que le permite redibujar un espacio común diferente del establecido por el orden, actuando como arte (experiencia específica), pero también como no-arte (promesa de comunidad).

Por otro lado, las dos formas de representación - la de la supresión del arte en la comunidad y la de la separación entre ambos- si bien se oponen, han funcionado juntas en un tipo especial de arte: el arte crítico o político. Aquí se produce un acuerdo, una "tercera vía" (Rancière, 2005, 2006b) entre las dos lógicas políticas de la estética, pero subyace una tirantez entre ambas. En este sentido, para Rancière, el centro de la cuestión no es la oposición entre arte moderno y postmoderno, es decir, entre un arte autónomo y otro en el que sus límites se han desplomado, sino el intercambio entre arte y no-arte. Así, "el arte político siempre es fruto de algún acuerdo específico, no entre la política y el arte, sino entre las dos políticas de la estética. La tercera vía se ha hecho posible merced a un juego constante en la frontera y la falta de frontera entre arte y no arte" (Rancière, 2006b, p. 9). Este choque, que es el encuentro entre heterogéneos, se ha producido hasta los años sesenta a través de la forma polémica como se ponían en relación el arte y el no-arte.

Podemos ver la forma particular como se pone en juego el encuentro entre las dos formas de representación mencionadas en "Divisor" de Lygia Pape. Esta acción consistió en que cada participante colocara su cabeza en las perforaciones de un amplio paño de tela y caminaran todos juntos por la ciudad. Se desarrolló por primera vez en 1968 en una favela vecina a la casa de la artista $\mathrm{y}$, según su testimonio, los niños rápidamente comprendieron el funcionamiento y el carácter lúdico de la acción (Pape, citada en Machado, 2008). Aquí encontramos funcionando al mismo tiempo y de forma combinada la lógica de la participación comunitaria, en la que el público pasa a formar parte de la obra, haciendo difícil la distinción entre arte y no arte, y la lógica de la separación, dado que no hay un mensaje explícito que implique un tipo de concientización política, sino una invitación a vivir el arte y el espacio público de un modo diferente del que ofrece el orden normalizado $\mathrm{y}$, por lo tanto, una incitación a la construcción de ese espacio. Estas dos políticas de la estética operan a través de la separación, así como de la supresión, "interrumpiendo las coordenadas normales de la experiencia sensorial [...], ligando lo que es propio del arte a una cierta manera de ser de la comunidad" (Rancière, 2005, p. 15).

Para comprender la complejidad de la teoría de Rancière parece necesario precisar que al mismo tiempo que identifica tres regímenes tipificados de identificación del arte, estos se corresponden (en otro nivel) 
con tres formas de relación entre la estética de la política y la política de la estética. Así hay, en primer lugar, un modo de representación que parece propicio para la acción de la comunidad disensual; en segundo lugar, la creación por parte del arte de un modo de vida comunitario nuevo; finalmente, un arte distanciado del compromiso político revolucionario. Como se ve, estos tres operan del mismo modo que los tres regímenes: representativo, ético y estético, pero en este caso constituyen modos diferenciados en cuanto a la conexión que producen entre estética y política. Estos, si bien se presentan tipificados, se combinan cuando actúan en un espacio y tiempo determinados.

Rancière ha trabajado también sobre la figura del espectador y ofrece una teorización acorde a sus argumentos generales. La idea de espectador para este autor está íntimamente relacionada con la del alumno que puede aprender sin un maestro "explicador" (Rancière, 2008), puesto que en ambos casos se trata de la posibilidad de la emancipación. Rancière critica la mirada platónica que sostiene que el espectador cumple un rol pasivo, puesto que mirar se asimila a pasividad. También analiza las dos posibles salidas que se han planteado a este problema, ambas basadas en la suposición de una estrecha relación entre teatro y comunidad. La primera propone producir en el espectador algún tipo de reacción o búsqueda de sentido al presentarse un espectáculo extraño o inusual; mientras que la segunda sustenta la necesidad de romper con la distancia que existe entre espectador y acción, involucrándolo directamente en la obra. Frente a estas miradas, Rancière presenta otra que parte de la renuncia a la identificación entre teatro y comunidad. Su propuesta se basa en una concepción del espectador donde este no es un ser pasivo, aunque no forme parte de la acción dramática o performática en sí misma, por cuanto sostiene que "mirar es también una acción que confirma o que transforma esta distribución de las posiciones. El espectador también actúa [...]. Observa, selecciona, compara, interpreta. Liga aquello que ve a muchas otras cosas que ha visto [...]" (Rancière, 2010a, p. 19). En este sentido, se trata de un espectador emancipado porque no precisa de un actor, un director o un maestro que le indique qué tiene que hacer o qué significado tiene tal o cual cosa. Allí opera una supresión: no tanto la que elimina la distancia entre artista y espectador, sino la que prescinde de una relación directa entre artista, obra y espectador. De este modo, para Rancière la emancipación del espectador implica que no es necesario que el artista lo instruya como el maestro a través de la explicación en el proceso que Jacotot llamó "embrutecimiento" (Rancière, 2008) - ni producir una forma de conciencia específica, ya que estas ideas se basan en un supuesto no igualitario. En cambio, el filósofo señala que lo que opera, como en el régimen estético, es una disociación entre los tres términos (artista, obra y espectador), en la medida en que cada espectador realiza un proceso de traducción, a su modo, a través de una serie de asociaciones y disociaciones que implican, además, una verificación de la igualdad.

Una de las formas como puede pensarse esta definición de Rancière es analizando un caso específico del arte brasileño: la propuesta que Helio Oiticica produjo en los "Parangolés" (imagen 4). Estas acciones performáticas se llevaban a cabo durante los años sesenta en espacios abiertos, donde 
Imagen 4. HélioOiticica, Miro de Mangueirawith P 02 ParangoléBandeira 01 (1964)

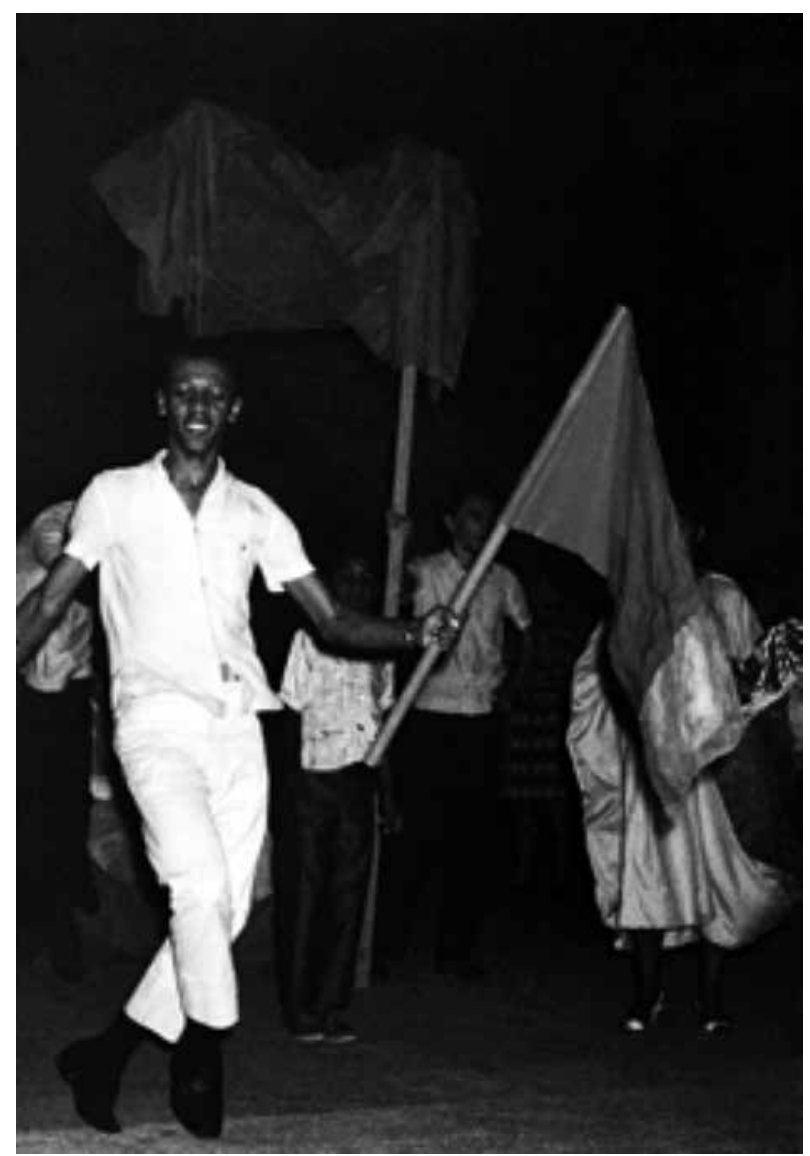

Fuente: Museum van HedendaagseKunstAntwerpen, Antwerpen.

alguien -cualquiera que esté allí presente- se vestía con una capa o bandera y danzaba o se movía a su manera al ritmo de la música en el marco de una reunión colectiva. Estas acciones estaban íntimamente ligadas a la práctica popular de sambar-que el propio Oiticica había aprendido a partir de su acercamiento a la favela y la escola de samba- y especialmente al vínculo con el cuerpo: una relación precaria, temporal e intensa, donde cada uno podía expresarse sin reglas definidas ni indicaciones específicas sobre lo que el artista suponía que cada uno que participase del "Parangolé" debía sentir o transmitir. En este caso, podemos interpretar el modo como se da la combinación entre dos situaciones: en primer lugar, la concepción de un espectador libre - una de las máximas de los artistas neoconcretos brasileños era "a arte como um exercício de liberdade" (Pequeno, 2013, p. 43) - que pudiese intervenir, interpretar o resignificar las obras, acciones performáticas $\mathrm{u}$ objetos sin la necesidad de una explicación por 
parte del artista y, en este sentido, estaría emancipado. En segundo lugar, como en el mencionado "Divisor" de Pape, se da el cruce de las dos formas de representación estética y ética, por cuanto se concibe una distancia entre artista, obra y espectador, es decir, que funciona como una forma de disyunción, pero al mismo tiempo hay una invitación a la participación comunitaria y una reivindicación de una práctica artística popular que tiende a diluir el límite entre arte y comunidad en acto. Así, en estas acciones, la implicación del espectador también está dada por la propuesta participativa del artista, que Rancière ve desde un punto de vista crítico. Al mismo tiempo, en los "Parangolés" se expresa una particular relación entre arte y espacio público, ya que no se trata solo del uso de ese espacio, sino que tiende a implicar la libertad en la expresión y experiencia de los cuerpos en ese sitio: cuerpos comunes en espacios también comunes, ambos pasan a ser significados o construidos colectivamente de un modo diverso al establecido por el orden normalizador que, desde 1964, se había vuelto, además, dictatorial.

\section{RICHARD: POLÍTICA, DISLOCACIÓN Y ARTE CRÍTICO}

\section{La política como agregación de sujetos y discursos}

Al igual que con Rancière, es necesario reponer en primer lugar la perspectiva teórico-política de Nelly Richard para comprender luego el lugar que da al arte en ese marco. En algunos de sus escritos, la autora explica qué entiende por lo crítico-político y su relación con el orden, pudiéndose observar una vinculación con el pensamiento de Ernesto Laclau y de Jacques Rancière.

Como parte del pensamiento posfundacional, la autora sostiene que en los conflictos políticos nunca es posible saber cómo se van a entretejer las relaciones de poder-contrapoder-nuevo(s) poder(es), ya que no existe una verdad absoluta, fundante y originaria. En este sentido, que algo sea antidominante es el resultado contingente de prácticas multiarticuladas (entre lo constituido adentro- y lo constituyente - afuera-), cuya heterogeneidad lleva a cambiar qué se entiende por "revolucionario" según los contextos (tanto nacionales como microlocales) en los que interviene la crítica política (Richard, 2013, p. 246). De esta forma, Richard (2013) afirma que

\section{[...] las insurgencias y rebeliones de lo} disconforme que irrumpen o dislocan parcialmente las estructuras de consolidación del orden injustamente antisocial que instauró el neoliberalismo, deben seguir expresando sus reclamos por mayor autonomía participativa para que los "ruidos" que emite ese "desorden democrático" interfieran con cualquier tipo de gobernabilidad que busque hegemonizar lo político. (p. 248) [el énfasis es nuestro]

En esta cita aparecen dos referencias y aportes que se pueden vincular con Ernesto Laclau y Jacques Rancière y que asimismo dan cuenta de la raíz posfundacional del pensamiento de Richard. Por un lado, la referencia a la dislocación y por otro a la imagen de "ruido". En el primer caso, con dislocación, Laclau refiere que el momento de imposibilidad o fracaso de la estructura "es un quiebre en la capacidad de dar sentido, de dar 
explicaciones lógicas dentro de la estructura", es el "momento de pura eventualidad" y "es la forma misma de la posibilidad, en tanto los procesos y las opciones pueden tomar cualquier dirección" (Muñoz, 2006, p. 126). Según Laclau (1997) el momento dislocatorio es aquel en el que se interrumpe la posibilidad de la simbolización en las prácticas cotidianas por las cuales un momento de recomposición pasa a ser necesario. La dislocación en una comunidad puede ser tan profunda hasta el punto de que la vida de la gente ha sido radicalmente interrumpida, por lo cual esta necesita reorganizar todo. En este sentido, Richard hace referencia a acciones que irrumpen y se constituyen en distorsionadoras del orden, y de esta manera evidencia su contingencia. Por otra parte, la metáfora del ruido es utilizada por Rancière en $E l$ desacuerdo. Filosofía y Política (2007a). Allí, el autor francés establece la diferenciación entre quienes pueden hablar y quienes hacen "ruido" (Rancière, 2007a, pp. 36-37, 44-45, 72), siendo estos últimos la "parte de los sin parte", quienes emiten sonido y no palabras. Como señalamos antes, para Rancière la policía define los modos de ver y decir, dicta que una palabra sea entendida como perteneciente al discurso y otra al ruido. Así, quedan configurados el "ruido de la revuelta o [la] palabra que expone la distorsión" (Rancière, 2007a, p. 73). Justamente, sostenemos que Richard retoma esta cuestión en su argumentación para explicar y definir la política.

En Crítica y política (2013) la autora afirma que los grupos movilizados de la sociedad, ${ }^{9}$ deberían ser capaces de formular diversas gramáticas de intervención político-sociales, cuyos ritmos de acción varían según

9 Richard (2013) analiza el caso del movimiento estudiantil chileno de 2011. los momentos de agrupamiento o enfrentamiento de las identidades en juego. Para ella, no todo puede ser mero acontecimiento y disrupción del orden, sino que son necesarios tiempos más largos de consolidación, de agregación e integración plurales de los sujetos y discursos. En este sentido, remarcando esta necesidad, Richard critica la concepción rancièriana de "momento político", en pos de una revaloración de una necesidad articulatoria que expanda el potencial de transformación de un reclamo puntual hacia el resto de la sociedad. Para ello, la autora sostiene que es necesario "diseñar modos de articulación-traducción entre sitios y posiciones que deben incluir variados puntos de antagonismos sociales, pero también de negociación política" (Richard, 2013, p. 217). Estas articulaciones y traducciones van desde los aparatos ya formados (asociaciones, sindicatos, organizaciones, partidos) y los poderes establecidos (el Estado y sus aparatos ejecutivos y legislativos) hasta los colectivos en gestación y las instituciones por transformar (Richard, 2013).

Por otro lado, Richard no suscribe a las tesis poshegemónicas que decretan la prescindencia del Estado en nombre de un pueblo que se autopotencia alejándose de todo lo instituido (2013). Sostiene que lo estatal es una conformación político-institucional susceptible, como otras, de fisuras que no tienen como único destino ser reabsorbidas por lo dominante. Richard establece además una distinción entre la política, en su versión instrumental y lo político, por cuanto

[...] antagonismos de poder y representación en torno a las prácticas de constitución de lo social; los choques de identidades agitados por quienes no 
se sienten parte del reparto hegemónico (un reparto que divorció lo social de lo político y que subordinó lo político a lo económico, sofocando mediante el consenso forzado el "ruido sin sentido" del "desorden democrático) y por quienes apelan, para transformar las injusticias de dicho reparto, a una redistribución de lo público y lo privado. Volver a conquistar esta dimensión intensiva de lo político supone abrirse a la incorporación de todas aquellas demandas (de clase, raza, etnia, género) que luchan contra las capturas de la identidad en aparatos de clasificación dominantes para que lo igualitario se expanda horizontalmente a subjetividades diferenciadas. (2013, p. 250)

Podemos ver en la anterior cita las similitudes terminológicas y conceptuales que tiene la autora con Rancière. La noción de "reparto hegemónico" se asemeja a la de "reparto de lo sensible" en la propuesta del filósofo francés $\mathrm{y}$ "consenso forzado" nos remite a la misma noción - consenso- como oposición a la política en Rancière (2007a, 2010b). Por último, los términos aparatos de clasificación dominantes y subjetividades diferenciadas nos recuerdan el texto "Política, identificación y subjetivación" (2000), donde Rancière expone que la política va de la mano de la subjetivación, una des-identificación, una modificación de las capacidades y propiedades de los que estaban identificados en una cierta jerarquía del orden policial, lo que posibilitala emergencia de nuevos sujetos de enunciación.

\section{El arte político-crítico como generador de alternativas de sentido}

Nelly Richard ha escrito numerosos libros en los cuales abordó la relación entre arte y política. En primer lugar, establece la diferencia entre arte militante y arte de vanguardia. En segundo lugar, describe qué entiende por arte crítico. Por último, propone la distinción entre "arte y política" y "lo político en el arte". A continuación iremos desentrañando estas cuestiones, las cuales, además, se encuentran estrechamente ligadas.

Para diferenciar entre arte militante o de compromiso y arte de vanguardia, Richard (2005) dice que el primero refiere a aquel que pretende "ilustrar" su compromiso con una realidad política ya dinamizada por las fuerzas de transformación social. Es el arte que, en América Latina, adquiere valor en los años sesenta. Las obras de arte adherían a la noción de pueblo y de revolución como significados trascendentales con el objetivo de producir una toma de conciencia. En este sentido, la obra era un reflejo de la sociedad, un vehículo del mensaje del artista y un instrumento funcional a su militancia política. En Chile, el arte militante emergió con fuerza en los años setenta durante la Unidad Popular (1970-1973). En ese periodo, se realizaban exposiciones a partir de la serigrafía, con el fin de acercar el arte al pueblo y contra la idea burguesa de obra única.

Un ejemplo del arte militante de aquellos años fue la producción de la Brigada Ramona Parra (вRP), perteneciente al Partido Comunista de Chile, que a través de murales colectivos daba cuenta de las consignas del Gobierno socialista de Salvador Allende (imagen 5). Posteriormente, a la elección de Allende en 1970, las Brigadas integraron los lemas característicos de la campaña allendista con coloridos dibujos e imágenes representativas de los componentes de la 


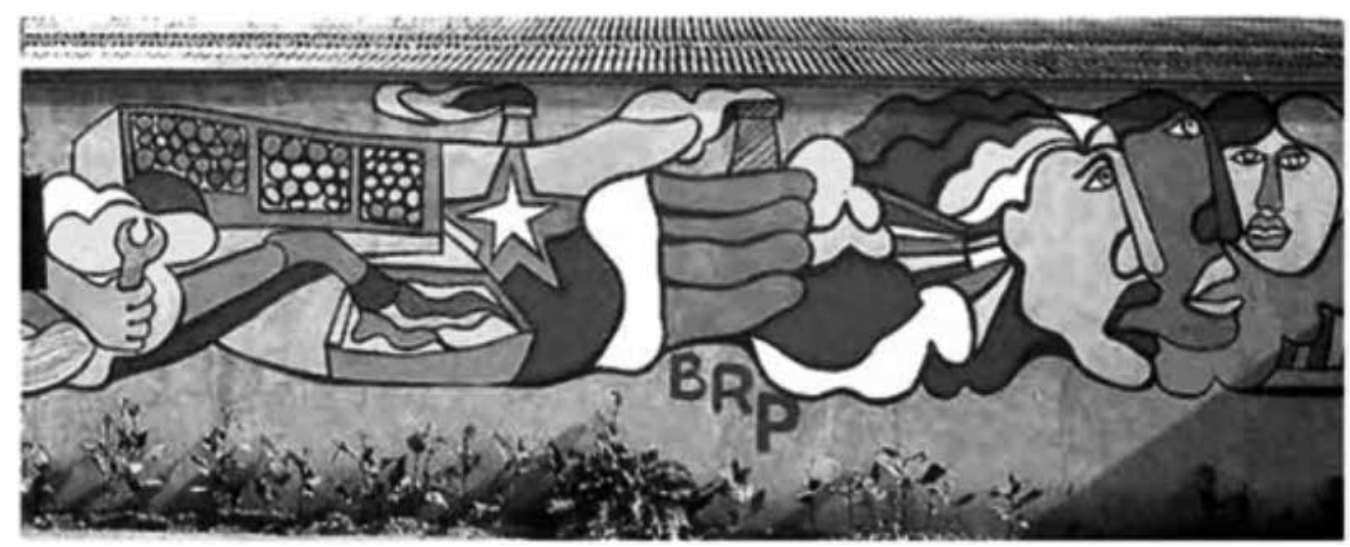

Fuente: Portal Memoria Chilena.

realidad nacional, tales como los trabajadores, la familia, referencias a la geografía del país. A este periodo corresponde, por ejemplo, la confección del mural El primer gol del pueblo chileno (1971) en la comuna de La Granja, en cuya elaboración participaron la BRPy el pintor chileno Roberto Matta (19112002). El mural fue pintado en conmemoración del primer aniversario del Gobierno de Salvador Allende. Sin embargo, en 1972, y debido al clima de agitación y polarización social, las brigadas se vieron obligadas a abandonar el tipo de imagen que venían realizando (dibujos, paisajes simbólicos, figuras humanas), para retomar la producción exclusiva de textos o frases que apoyaban al Gobierno de la Unidad Popular. Esto tenía el objeto de ser una estrategia de defensa del Gobierno como una forma de comunicación alternativa a la prensa opositora. El muralismo callejero entonces tenía el objetivo de concientizar visualmente al espectador, educaba a través de la denuncia social e informaba a través de las consignas sobre los acontecimientos del país. Con el advenimiento de la dictadura de Pinochet, el mural de Matta fue tapado con el objeto de destruirlo, al igual que todas las expresiones que representaban al comunismo o al pensamiento de izquierda en general.

En el contexto argentino, podemos mencionar como arte (y artista) militante a las producciones de Ricardo Carpani (19301997). Sus obras hacen foco en temáticas como el desempleo, los trabajadores y los pobres, así como en temas de índole nacional. Tuvo una vinculación orgánica con el sindicalismo argentino, en particular con la Confederación General del Trabajo (CGT) de los Argentinos, liderada por Raimundo Ongaro, para la que colaboró diseñando afiches. Asimismo, Carpani supo delinear, a través de sus murales y afiches políticos una iconografía propia e identitaria de la clase trabajadora nacional. El afiche "Libertad y amnistía" de 1973, creado para la campaña electoral del candidato peronista Héctor José Cámpora (imagen 6), representa un tipo de arte de compromiso. En el afiche, bajo la imagen de trabajadores, aparece el texto "Libertad y amnistía a todos los 


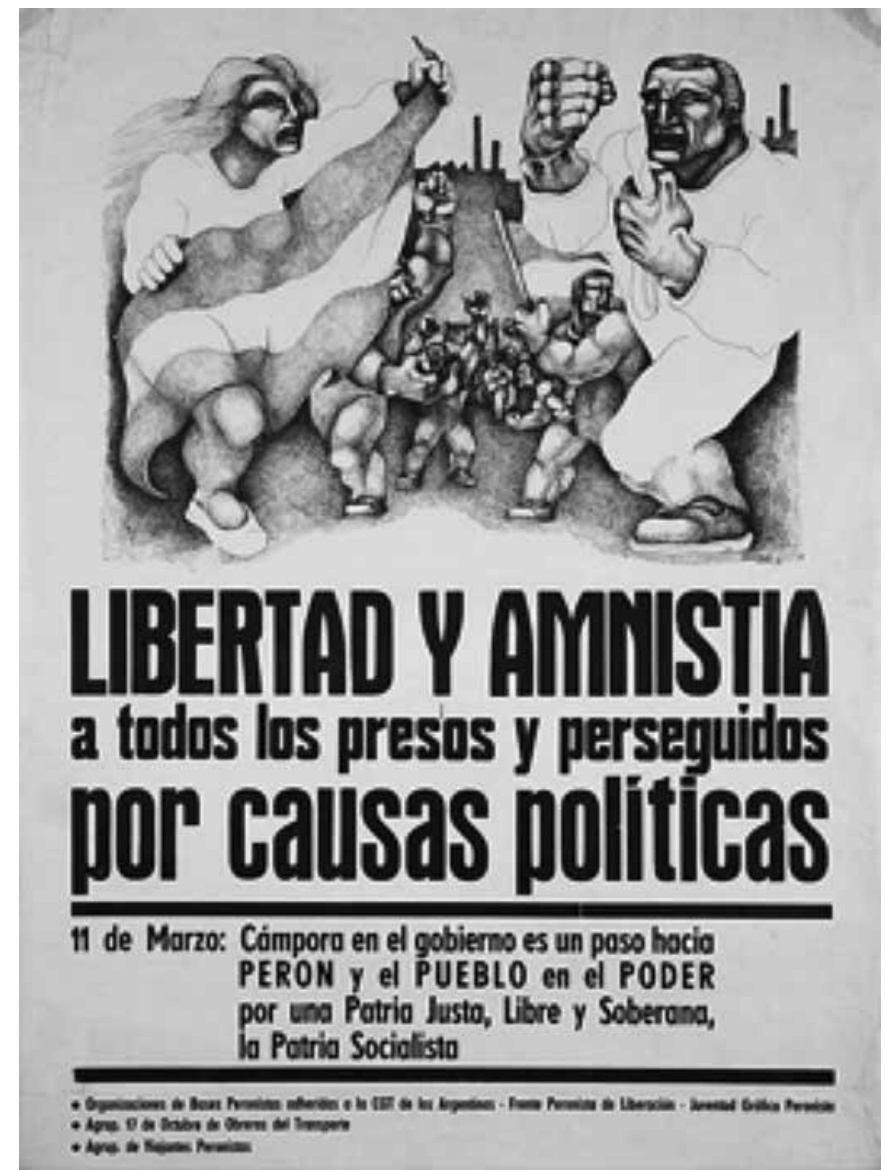

Fuente: Museo del Bicentenario, Buenos Aires.

presos y perseguidos por causas políticas [...] Cámpora en el gobierno es un paso hacia PERÓN y el PUEBLO en el PODER por una Patria Justa, Libre y Soberana, la Patria Socialista" (afiche Libertad y amnistía, 1973, Museo del Bicentenario). Se constituyó, así, en un vehículo del mensaje del artista, en consonancia con su militancia política y reivindicando el lugar del "pueblo" en el marco de un horizonte revolucionario.

El arte de vanguardia, por su parte, es definido por Richard como aquel que busca anticipar y prefigurar el cambio, usando la transgresión estética como detonante anti-institucional (2005, 2011, 2013). Es decir, la experimentación de nuevas técnicas y formatos, y la disolución de fronteras entre el sistema artístico y la praxis social son procedimientos que operan contra el canon academicista, expresando el deseo emancipatorio de las vanguardias. Artistas como el Grupo Signo (José Balmes, Gracia Barrios, Alberto Pérez, Eduardo Martínez-Bonatti), Francisco Brugnoli, Virginia Errázuriz y Juan 
Imagen 7. Francisco Brugnoli, Siempre gana público (1965)

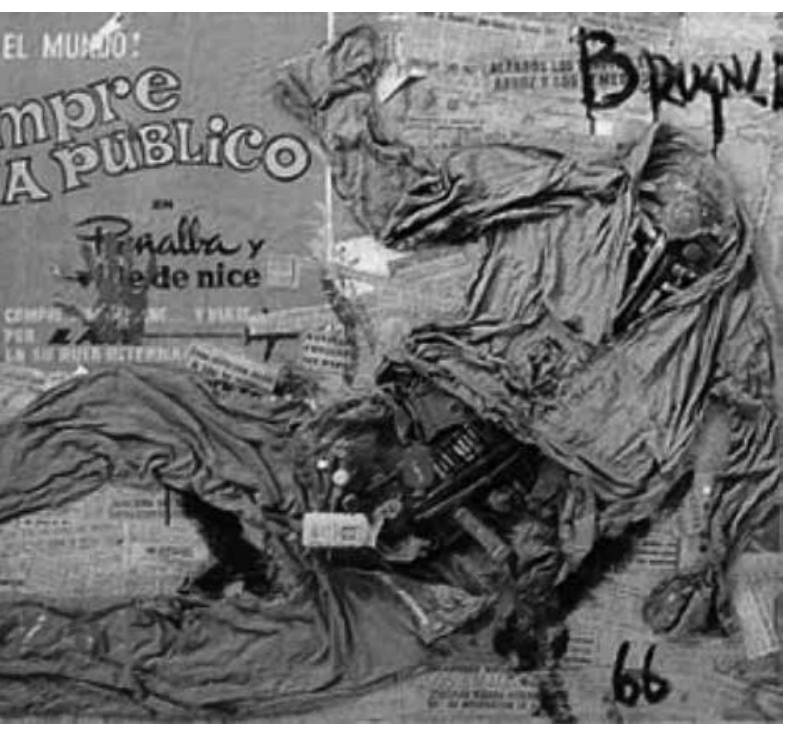

Fuente: Portal de la educación del Gobierno de Chile.

Pablo Langlois, entre otros, formaron parte de la primera vanguardia chilena. Tenían influencias que venían del informalismo, del arte pop y del povera italiano. Podemos nombrar el ejemplo de Francisco Brugnoli (1935-), artista que hacía un pop objetual con reminiscencias de la obra de Rauschenberg. Brugnoli trabajaba ensamblando elementos de uso cotidiano y desechos urbanos, descontextualizándolos, suspendiendo sus sentidos y reactivándolos en un nuevo montaje (imagen 7). Los collages de Antonio Berni, mencionados anteriormente, también pueden enmarcarse en esta lógica vanguardista, aunque sin configurar el carácter anti-institucional mencionado por Richard.

Para la autora, sin embargo, el arte de compromiso y el de vanguardia han fracasado puesto que posteriormente renunciaron a varias de sus características constitutivas. Así, en el caso de la vanguardia, hoy su carácter transgresor ha perdido fuerza y se ha museificado. ${ }^{10}$

Por otro lado, en el contexto de la dictadura militar chilena, emerge lo que Richard llamó la Escena de Avanzada, un colectivo de artistas que durante el primer tiempo de la dictadura generó obras disidentes del contexto político, caracterizadas por la experimentación neovanguardista y cercanas al conceptualismo, con un lenguaje que, a través de metáforas, sobrepasaba la censura. Una de las características principales de la Escena de Avanzada fue que reformuló el nexo entre arte y política. Además, los artistas que la conformaron cruzaron la frontera entre los géneros, ampliando los soportes técnicos del arte al cuerpo y a la ciudad. Entre ellos se encuentran Carlos Altamirano, Juan Castillo, Eugenio Dittborn, Diamela Eltit, Carlos Gallardo, Carlos Leppe, Gonzalo Mezza, Ximena Prieto, Lotty Rosenfeld, Francisco Smythe y el poeta Raúl Zurita.

Entre las producciones de estos artistas, podemos analizar las de Lotty Rosenfeld (1943-). Para el registro de sus acciones, la artista utilizaba la fotografía y el video. En 1979 realizó la acción denominada Una milla de cruces sobre el pavimento en Manquehue (Santiago de Chile) (imagen 8). En esta obra se evidencia, por un lado, la experimentación en el espacio de la ciudad y, por otro, la experimentación con los signos:

10 Observamos aquí una similitud entre la caracterización que Nelly Richard realiza de las vanguardias y su fracaso y la teoría de Peter Bürger (1987). Para Bürger, los procesos posteriores a la segunda guerra mundial demostrarían que los movimientos de vanguardia fracasaron en su búsqueda de cancelar la división arte/vida. Así, las neovanguardias representarían una nueva fase, que cancela el proyecto de la vanguardia histórica, al incorporarse rápidamente a la institución arte. 
La insistencia de la artista de trabajar en torno a un signo único: la cruz (o el signo más), lo enriquece, abre nuevas posibilidades de interpretación: [según Rosenfeld] 'Cada una de las personas lo enfoca como lo quiere ver y eso me interesa. Mucha gente va a querer ver la cruz cristiana: mucha gente verá un signo de muerte; otros van a ver tanto eso como lo otro, se darán cuenta que hay una señal dada [...] Estoy cuestionando el código de tránsito, pero también todos los códigos, todo lo que nos reglamenta, lo que nos va guiando, lo que nos va haciendo como se quiere que seamos; el poder en definitiva'. (Saúl, 1986, pp. 28-29)

Para Richard, las rupturas de la Escena de Avanzada están relacionadas con el intento de reconfigurar articulaciones de sentido que, gracias a la insubordinación de las formas y conceptos, crearan imágenes antitotalitarias y antirrepresivas para ayudar a quienes se involucraban en ellas a zafarse del autoritarismo. La censura de la política y lo político durante los años de la dictadura llevaron al arte a ser un medio sustituto (Richard, 1994): es decir, a ser el modo en el cual se expresaban las disidencias. De esta manera, la autora sostiene que la pulsión crítica del arte explora la insatisfacción, la disconformidad y el rechazo, que dentro de lo existente, dan la oportunidad de redibujar el universo de lo posible aunque sin aspirar a una revolución total. Según Richard (2013), "el arte crítico puede activar vectores de emancipación ${ }^{11}$ subjetiva

11 Richard aclara que comparte la definición de Benjamin Arditi de "política emancipatoria": "es la práctica que busca interrumpir el orden establecido y, por lo tanto, que apunta a redefinir lo posible, con el objetivo de instaurar un orden menos desigual y opresivo, ya sea a
Imagen 8. Lotty Rosenfeld, Una milla de cruces sobre el pavimento (1979)

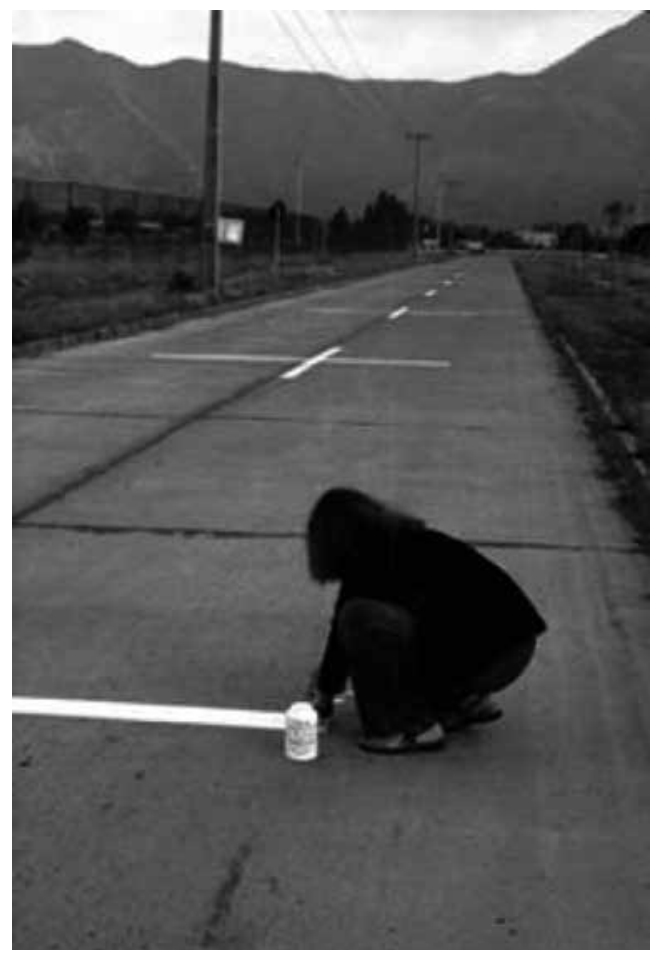

Fuente: Colección Museo de Arte Contemporáneo, Santiago de Chile.

que trabajen 'revolucionariamente' con el inconsciente social, sin tener la pretensión de que el mensaje de la obra entregue una clave de salvación universal para la humanidad entera" (p. 156).

Coincidiendo con la crítica que realiza Rancière al arte político que intenta transmitir un mensaje o alinearse a un programa de transformación histórica, Richard sostiene que la fuerza de emancipación que puede hoy desplegar el arte crítico-experimental sería aquella surgida de las fracturas de la

nivel macro o en las regiones locales de una microfísica del poder. Dicha práctica no describe un acto único y glorioso, sino uno performativo que enuncia el presente como tiempo de nuestro devenir otro" (2009, p. 176). 
representación. Estas fracturas son las únicas capaces de romper con la pasividad de la transmisión del sentido; de interrumpir la cadena lineal que va desde la producción de la obra (causa) hacia la recepción del espectador (efecto) en una dirección pre-trazada, para abrir así la posibilidad creativa, y favorecer de esta manera la emergencia de potencialidades enunciativas que no estaban previstas en el recorrido inicial entre origen (intención) y destino (cumplimiento). Esto hace que cada espectador actúe los significados de la obra según la inventiva de una lectura autónoma, "emancipadora", por cuanto no está subordinada a una lógica previamente unificada de inteligibilidad del mensaje. Vemos entonces que aquí también hay una similitud con la noción de espectador emancipado de Rancière. Sin embargo, inferimos que la referencia de Richard se circunscribe a las obras que apuntan a esas "fracturas" de la representación, mientras que para Rancière todos los espectadores pueden emanciparse, puesto que existe una base común igualitaria, independientemente de las obras. Asimismo, no es casual que la autora haya denominado al colectivo de artistas como Escena de Avanzada, con la carga de significado que le atribuye, con lo cual parecería recuperar el concepto de Rancière de escena disensual, es decir, la puesta en obra de una nueva topografía de lo posible.

Siguiendo con la argumentación de la autora, la criticidad del arte depende así de cómo su producción de significados es capaz de llevar al espectador a optar por la multivocidad de lo suspensivo-interrogativo (convirtiendo para ello la forma y la sustancia del lenguaje en su principal material de experimentación creativa), en lugar de confiar en la univocidad de lo afirmativo/ negativo de un mensaje que se pronuncia sobre los contenidos sociales desde la literalidad del "sí" de la adhesión o del "no" de la protesta (Richard, 2013). De esta manera, sostiene que el arte es poderoso como tal no cuando actúa comunicativamente al igual que una consigna política, una intervención cultural o un testimonio periodístico, sino cuando explora lenguajes aún no modulados, identidades no finitas, significados entreabiertos (Richard, 2013). Asimismo, una obra crítica se caracteriza por confeccionar modos colectivos de activar el ensamblaje de lo visual con lo político-social para que ambos formatos se desborden mutuamente. Podemos señalar en este caso una diferencia con Rancière, por cuanto - como se dijo antes - sostiene que el arte no puede crear un nosotros al igual que la política, sino que propone una distinta representación de la realidad, una ficción diferente de la dominante.

Para Richard, una práctica crítica debe "desinocentar la mirada", generar rupturas intersticiales en los mensajes hegemónicos (1994, p. 103), en las formas constituidas oficiales de representar el mundo. Así, las prácticas críticas desmontan el supuesto ideológico de la transparencia, evidenciando el carácter artificial de los signos (lo que Rancière llama ficción); develan la arbitrariedad de las reglas del código de visibilidad dominante y rearticulan las estrategias de puestas en escena de los cuerpos y de los signos culturales (Richard, 1994). En suma, provocan conflictos de representación en los códigos de significación cultural.

Por último, la autora realiza la distinción entre arte y política, y lo político en el arte. 
Tal como mencionamos en la introducción, la relación entre arte y política parece establecer una relación de exterioridad entre ambos términos. Esta relación supone una vinculación expresiva y referencial que descansa en una correspondencia lineal entre forma y contenido, como si el "contenido social" fuese un dato ya elaborado con anterioridad a la obra: un dato que dicha obra luego tematiza según un determinado registro de equivalencias y transfiguraciones de sentido (Richard, 2005, 2011). Por su parte, como ya referimos, "'lo político en el arte' designa una articulación interna a la obra que reflexiona críticamente sobre su entorno social desde su propia organización de significados y su propia retórica de los medios, desde sus propios montajes simbólicos" (Richard, 2005, p. 17). Así, lo político en el arte rechaza la correspondencia entre forma artística y contenido social, nombrando una fuerza crítica de interpelación y desacomodo de la imagen (Richard, 2005, 2011). Cuando la autora se pregunta qué sería hoy lo político-crítico en el arte, responde que no es posible creer que una obra sea política o crítica en sí misma, sino que se define en acto y situación, siendo una operación localizada cuya eficiencia depende de la particular materialidad de los soportes de inscripción sociales que se propone afectar.

De esta manera, lo político-crítico de una obra depende del contexto, las fronteras que una obra se propone traspasar, las presiones que pueda ejercer contra ciertos marcos de vigilancia, prescripciones e imposiciones y la capacidad que tenga de descentrar los lugares comunes de lo oficialmente consensuado (Richard, 2011). En el argumento de Richard vemos varios puntos de contacto con la propuesta de Rancière. Por un lado, las características que otorga Richard al arte crítico se asemejan a las ofrecidas por el autor francés en relación con el régimen estético (cuestión sobre la que profundizaremos en las conclusiones). Por otro lado, la relación entre emancipación y arte para Rancière, desde la noción del espectador emancipado, también aparece en cierto sentido en los desarrollos de Richard. Al tratar las fracturas de la representación y los significados que el arte crítico puede generar, la autora sostiene que este rompe la relación causa-efecto y la lectura unívoca, es decir, se establece una ruptura en términos de la pasividad de la transmisión del sentido.

Sintetizando, el arte crítico para Richard tiene la tarea de desnaturalizar el sentido, pero también y en relación con ese objetivo, debe trazar vectores de subjetivación alternativa "que potencien la alteridad en tanto fuerza de desclasificación en contra de las uniformaciones seriales, la programaticidad del sentido, las ortodoxias de representación, los guiones identitarios predeterminados, las asignaciones fijas de papeles y categorías homogéneas" (Richard, 2007, p. 104). El arte, asimismo, puede producir una dislocación que sea a la vez perceptiva e intelectiva ( $\mathrm{Ri}$ chard, 2007); es decir, las imágenes también invitan a reflexionar, pensar, problematizar. En este sentido, el arte crítico busca romper la unidireccionalidad de la experiencia del espectador, repolitizando su mirada. Y en esto vemos nuevamente los paralelismos con la propuesta rancièriana. El arte crítico entonces genera una afectación. Esto refiere para la autora a dos cuestiones: por un lado, al afecto, a la apelación a los sentidos y al deseo; por otro, a los efectos de la obra, a la concepción del significado como algo producido activamente con el espectador. 


\section{REFLEXIONES FINALES}

Con el objeto de avanzar y complejizar lo trazado en los apartados anteriores, se realizan algunas comparaciones entre Rancière y Richard, en función de sus similitudes y diferencias y de analizar algunos casos del arte latinoamericano.

Una de las tesis compartidas por los autores aquí estudiados es que ninguno concibe como productiva la idea de que el arte y la política funcionen como dos campos o esferas separados. Tal como se analizó a lo largo del artículo, Rancière diferencia entre estética de la política y política de la estética. Para el filósofo "las artes prestan a la dominación o a la emancipación lo que tienen en común con ellas: posiciones y movimientos de cuerpos, funciones de la palabra, divisiones de lo visible y lo invisible" (Rancière, 2002a, p. 28); es decir, asemejándose a una u otra lógica. Es menester insistir en que para este autor como no todo es política, tampoco todo es arte, por lo tanto, no todo arte es político. Es decir, puede haber formas de poder sin que haya política y puede haber poesía, pintura, música, escultura, sin que haya arte, por cuanto esa condición depende de los regímenes de identificación a los que ya se hizo referencia (Rancière, 2011).

En el caso de la propuesta de Nelly Richard, al definir la política, se refiere a la dislocación de las estructuras del orden en el mismo sentido que Rancière se refiere a los cambios que produce la estética de la política. Sin embargo, Richard no menciona que la dislocación tenga un efecto propiamente estético. Asimismo, como se señaló antes, sostiene que el vínculo entre arte y política ha sido identificado algunas veces como una relación de exterioridad entre ambos conceptos que termina denotando una correspondencia lineal entre forma y contenido, y otras donde lo político en el arte funciona como una articulación interna a la obra, es decir, donde el dispositivo artístico en sí reflexiona críticamente sobre su entorno social (Richard, 2005, 2011). El cuadro 1 resume la comparación:

Cuadro1. Relación entre arte y política

\begin{tabular}{ll}
\hline Jacques Rancière & Nelly Richard \\
\hline Estética de la política & $\begin{array}{l}\text { Dislocación de las } \\
\text { estructuras del orden }\end{array}$ \\
\hline Política de la estética & Lo político en el arte \\
\hline
\end{tabular}

Fuente: Elaboración propia

Por otro lado, estos dos autores establecen diferentes categorías para referirse al arte. En este punto también es posible hallar concordancias. En el caso de Rancière, este divide los regímenes de identificación del arte entre régimen ético, régimen mimético o representativo y régimen estético. Si bien el autor explica que funcionan como lógicas entrelazadas, es en el régimen estético en el que existe una política de la estética. Por su parte, Richard distingue dos modos de configuración histórica de la relación entre arte y política: el arte de compromiso y el arte de vanguardia, y además nos habla del arte crítico. Las categorizaciones propuestas por ambos autores son comparables. Pudo verse en qué sentido Richard define el arte de compromiso o militante como aquel que pretende "ilustrar" una realidad política, donde la obra se configura como vehículo del mensaje del artista que explicita su compromiso social. Así este arte es funcional a la militancia política. Homologable al arte de compromiso, es la categoría rancièriana de 
régimen mimético/representativo, definido como aquel que representa la intención de un autor y se transmite un mensaje captado claramente por el público. Por otro lado, el arte de vanguardia, según Richard, entre otras cosas, no busca reflejar el cambio social sino anticiparlo usando la transgresión estética. Sostiene la fusión emancipatoria arte/vida, la disolución de las fronteras de autonomía y especificidad del sistema-arte que lo separan de la praxis cotidiana. Existe una semejanza entre esta definición $\mathrm{y}$ el régimen ético de Rancière por cuanto en este no existe arte propiamente dicho, sino imágenes que se juzgan en función de su verdad intrínseca y de sus efectos, al tiempo que no hay separación entre arte $y$ vida, pues el arte se diluye y se convierte en comunidad. ${ }^{12}$ El cuadro 2 esquematiza esta comparación conceptual.

Cuadro 2. Categorías de arte

\begin{tabular}{ll}
\hline \multicolumn{1}{c}{ Jacques Rancière } & \multicolumn{1}{c}{ Nelly Richard } \\
\hline Régimen ético & Arte de vanguardia \\
\hline $\begin{array}{l}\text { Régimen mimético/ } \\
\text { representativo }\end{array}$ & $\begin{array}{l}\text { Arte de compromiso/ } \\
\text { militante }\end{array}$ \\
\hline
\end{tabular}

Fuente: Elaboración propia.

En el plano de las definiciones de arte político/crítico, podemos decir que esta noción está presente en ambos autores, aunque con sus propias características. Para Rancière, como ya se mencionó, en el régimen estético opera una experiencia estética que transmuta el orden social, modificando la división de lo sensible, pero desde su propia especificidad artística, sin fundirse en la comunidad, librando al arte de todo deber particular y sin efecto calculable de toma de conciencia o movilización política. Nelly

12 El régimen ético (Rancière) y el arte de vanguardia (Richard) solo nos parecen semejantes en este aspecto. De todas formas, la correspondencia categorial dependerá de cada caso en particular.
Richard, por su parte, sostiene que el arte crítico potencia una mirada que interpela e invita a las formas estéticas a destramar su complejidad de motivos e intenciones, veladuras y dilucidaciones del sentido (Richard, 2014). Así, lo político-crítico de una obra depende del contexto donde se produce, de las fronteras que se proponga traspasar, de la capacidad que pueda tener para descentrar lugares comunes consensuados, de las presiones que pueda ejercer contra ciertos marcos de vigilancia e imposiciones (Richard, 2011). En oposición a lo sostenido por el ideario vanguardista que se pretendía situado por fuera del mercado y las instituciones, según Richard (2014), la teoría contemporánea da cuenta de que es posible que los discursos de resistencia y oposición estén en alguna medida involucrados en las estructuras mercantiles e institucionales, por lo cual el arte tampoco sería ajeno a ello. Rancière (2005), por su parte, sostiene que las instituciones artísticas, como los museos, pueden servir para el cuestionamiento de la distribución de lo dado en cuanto permitan una reconfiguración de los territorios definidos por la división consensual.

Identificamos, pues, una fuerte similitud entre las características del arte crítico en Richard (que ella describe en relación a lo que ha denominado Escena de Avanzada) y el régimen estético en Rancière. Cuando Richard (2007) desarrolla qué es el arte crítico, entre otras cosas, dice que este: 1 . desnaturaliza el sentido; 2 . traza vectores de subjetivación alternativa, y 3 . produce una dislocación perceptiva e intelectiva. Estas mismas características van a ser atribuidas por Rancière $(2002,2005)$ a las producciones que se ubican en el régimen estético. Para el autor francés, en este régimen de identificación el 
arte se configura como disruptivo, poniendo en juego un espacio y una temporalidad diferentes, diseñando un paisaje nuevo de lo visible, de lo decible y de lo factible. Como ya se mencionó, la relación entre emancipación y arte para Rancière, desde la noción del espectador emancipado, también aparece en cierto sentido en los desarrollos de Richard. Al tratar las fracturas de la representación y los significados que el arte crítico puede generar, la autora sostiene que este rompe la relación causa-efecto y la lectura unívoca, es decir, se establece una ruptura en términos de la pasividad de la transmisión del sentido. De igual manera, el espectador emancipado rancièriano recrea lo que ve, traduce lo percibido, siendo esto una acción individual disociada de lo que el artista transmite. De esta forma, se generan interferencias en las fronteras entre mirar y actuar, entre lo pasivo y lo activo, en fin, se cuestiona la distribución de posiciones, el reparto de lo sensible.

En síntesis, en el cuadro 3 es establecida la siguiente correspondencia conceptual entre Rancière y Richard:

Cuadro 3. Categorías para referir al arte político

\begin{tabular}{ll}
\hline Jacques Rancière & Nelly Richard \\
\hline Régimen estético & Arte crítico \\
\hline
\end{tabular}

Fuente: elaboración propia.

Dos casos del arte argentino nos permiten poner en juego estas categorías y ver las similitudes entre Rancière y Richard. Sin embargo, el análisis y la correspondencia entre las categorías, dependerá de cada caso en particular.En primer lugar, para dar cuenta de las similitudes que encontramos entre el régimen mimético/representativo (Rancière) y el arte de compromiso/ militante (Richard), podemos analizar el caso de los grabados de los denominados Artistas del Pueblo en los años veinte (José Arato, Adolfo Bellocq, Guillermo Facio Hebequer, Agustín Riganelli y Abraham Vigo) (imagen 9). Los Artistas del Pueblo provenían de la clase trabajadora y se proponían reivindicarla, adherían a ideas políticas de izquierda -inicialmente al anarquismo y luego al anarcosindicalismo-, que articulaban y daban sentido a sus obras y a su actuación dentro del campo plástico de las primeras décadas del siglo xx. Tenían como referente a la ciudad moderna a Buenos Aires y buscaban realizar un arte social, para el pueblo (la clase trabajadora es el destinatario ideal para su obra), que sea entendible y aprehensible por este. Para ello, sostuvieron una estética realista y utilizaban técnicas que remitían al anarquismo: el trabajo manual, las técnicas artesanales como los diversos procedimientos del grabado o la talla directa en escultura. Producían, entonces, un arte militante que se orientaba a concientizar al pueblo, a mostrarle las injusticias de la sociedad capitalista y a promover la revolución. Esta es la razón principal que justificaba la elección de una estética realista, en tanto la misma permitía la realización de imágenes claras, accesibles a los sectores populares, y de técnicas como el grabado y la gráfica que favorecían la elaboración de un arte más accesible a todos, apartado del mercado artístico tradicionalmente detentado por las élites. Estos grabados pueden ser analizados entonces en el marco del denominado régimen mimético/representativo rancièriano, caracterizado tanto por la verosimilitud como por ser un dispositivo pedagógico que emite un mensaje directo con la intención de llegar intacto al público, lo que genera un impacto y moviliza a la acción. 


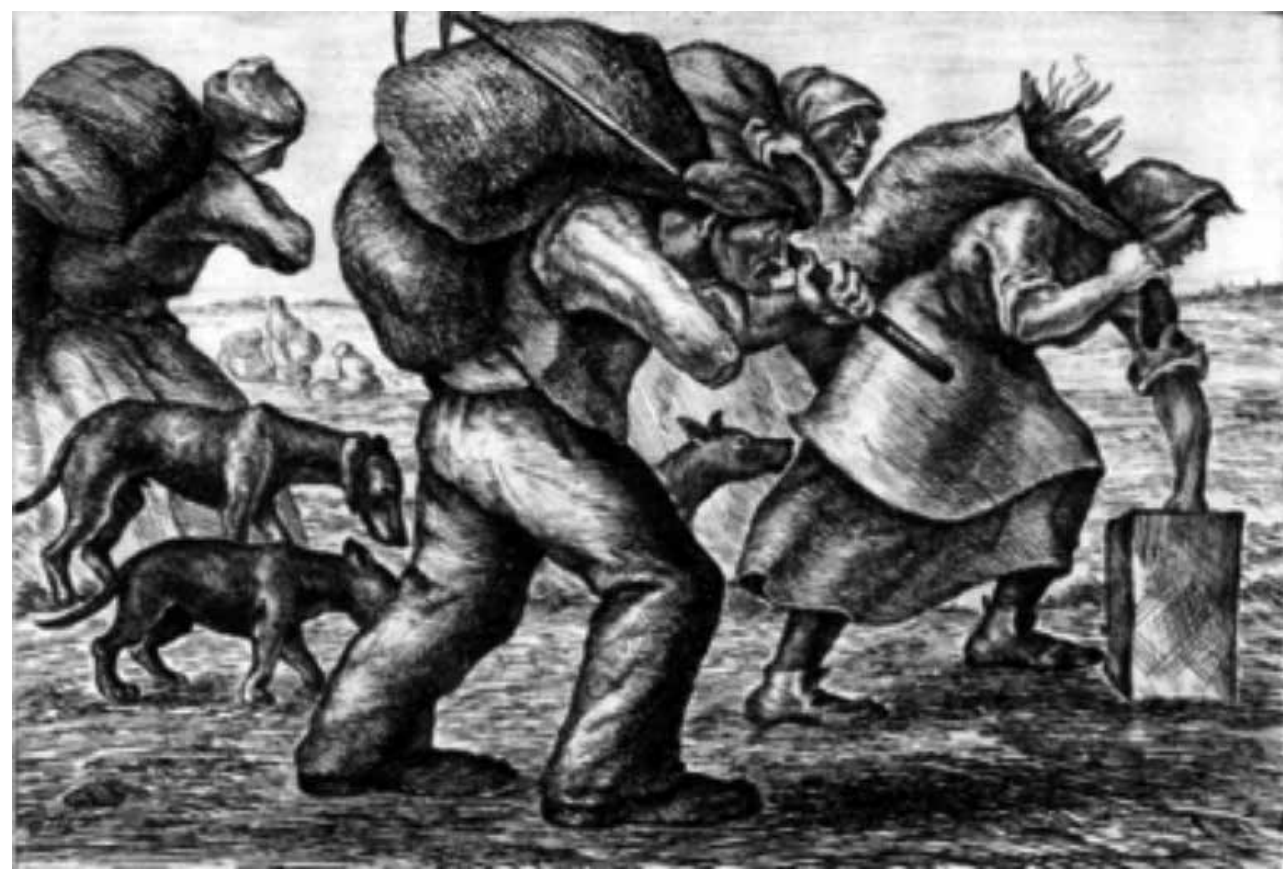

Fuente: Museo Nacional de Bellas Artes, Buenos Aires.

También, este tipo de obras se ubicaría bajo el concepto de arte de compromiso o militante de Nelly Richard, por cuanto pretende "ilustrar" una realidad política, explicitando el compromiso social de los artistas.

En cuanto a los puntos de contacto que mencionamos entre el régimen estético (Rancière) y el arte crítico (Richard), otro caso argentino puede echar luz sobre estos conceptos. Así, tomamos uno de los señalamientos $^{13}$ del artista Edgardo Antonio Vigo (1928-1997), "Manojo de semáforos", que fue pensado como experiencia estética cuyo fin era señalar un elemento cotidiano

13 Se trata de una serie de acciones en las cuales el artista se propuso destacar artísticamente algún hecho u objeto cotidiano. Para ahondar en el tema, ver Bugnone (2013). en la vía pública (imagen 10). El artista citó al público a través de la radio y los diarios locales a observar el semáforo ubicado en la intersección de dos importantes avenidas de La Plata. Al proponer una modificación de la mirada sobre un elemento cotidiano, Vigo planteó un distanciamiento de la familiaridad mantenida con el semáforo como objeto con una función determinada, la de mantener el orden del tránsito. Es decir, el artista proyectó realizar la experiencia de su contemplación estética, descentrando el rol del artista, del público y del concepto de obra. En este caso, como sostiene Bugnone (2013), se desubica la función del semáforo como artefacto utilitario, la del artista por cuanto no produce la obra ni tampoco asiste el evento y la del público que fue convocado 
Imagen 10. Edgardo Antonio Vigo, Manojo de semáforos (1968)

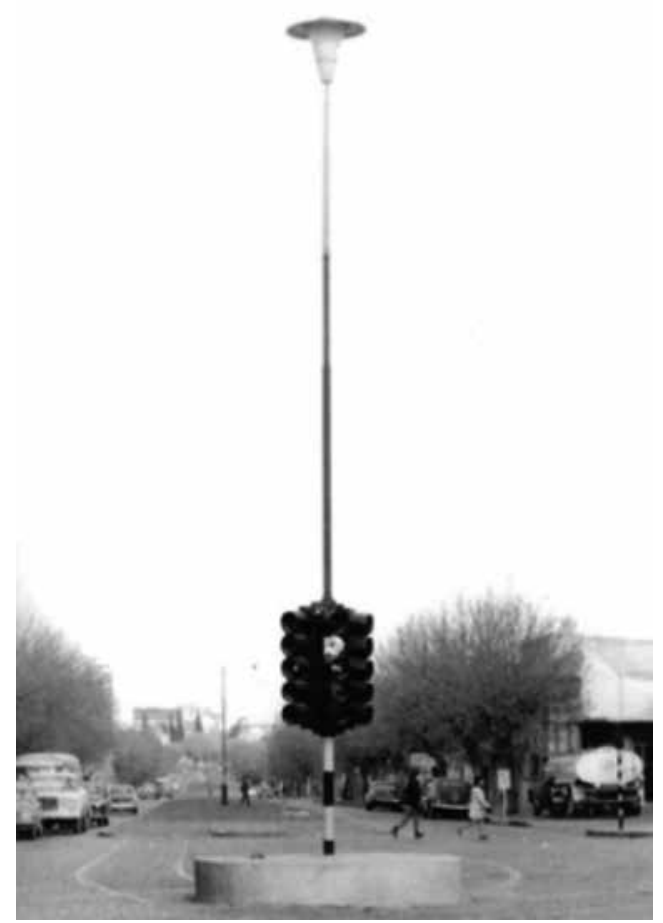

Fuente: Archivo Centro de Arte Experimental Vigo, La Plata.

a convertir ese objeto en un objeto artístico; todo ello en el marco de una dictadura que establecía reglas represivas de organización espacial y social de la ciudad. Podemos ver entonces que esta obra es factible de ubicarse dentro de lo que Rancière define como régimen estético y Richard como arte crítico, a partir de las características ya enunciadas: la configuración de otro reparto de lo sensible, distorsionando el uso cotidiano del espacio, sus usos y funciones esperadas y cuestionando los roles tradicionales del artista, del espectador y de la obra de arte.

Por último, es menester marcar que la principal diferencia que tienen los autores es la conceptualización de lo político, ya sea como encuentro de lógicas heterogéneas, en el caso de Rancière, o de antagonismo en un contexto hegemónico, en Richard. Esto tiene incidencias en la forma como cada autor entiende el lugar del arte y su potencial. En principio, en el caso de la propuesta rancièriana, no es posible pensar una articulación entre lógicas disensuales y si bien el arte crítico puede generar disrupciones en el continuum del orden policial, ello tiene un carácter eventual. En oposición, las teorizaciones de Richard permiten pensar que es posible (y deseable) que las prácticas artísticas críticas se articulen con otros niveles de lucha y de crítica social y cultural.

Para finalizar, procuramos que la exposición y el análisis comparativo de las teorías de Rancière y Richard presentados en este artículo abran nuevas perspectivas de investigación ligadas a la articulación entre arte y política que amplíen los horizontes actuales y vislumbren la potencia del arte latinoamericano.

\section{REFERENCIAS}

Arcos Palma, R. (octubre, 2009). La estética y su dimensión política según Jacques Rancière. Nómadas, (31), 139-155.

Arditi, B. (2009).La política en los bordes del liberalismo. Barcelona: Gedisa.

Benjamin, W. (1989). La obra de arte en la época de su reproductibilidad técnica. En Discursos interrumpidos I (pp. 15-57). Buenos Aires: Taurus.

Bugnone, A. (2013). El espacio público en la poética de Edgardo Antonio Vigo: los señalamientos. Revista digital de la Escuela de Historia, 5(8), 9-51. Disponible en http://www.memoria.fahce.unlp. edu.ar/art_revistas/pr.6403/pr.6403.pdf 
Burucúa, J. E. (Dir.) (1999). Nueva Historia Argentina. Volumen II Arte, sociedad y política. Buenos Aires: Editorial Sudamericana.

Capasso, V. (2015).Arte, política y espacio. Una revisión crítica desde el posestructuralismo(Tesis de posgrado). Universidad Nacional de La Plata, Argentina. Recuperado dehttp://sedici.unlp.edu.ar/ handle/10915/51586

Di Filippo, M. (2011).Walter Benjamin y Jacques Ranciere: arte y política. Una lectura en clave epistemológica. Revista de Epistemología y Ciencias Humanas, (3), 257-288.

Guerra, H. (2005). Nelly Richard: propuesta sistémica del análisis cultural. Tema y variaciones, (24),54-79.

La marca del agua (2013). Mamá política, no me abandones. Recuperado de https://www. youtube.com/watch?v=fChjz_o43jw

Laclau, E. (1997). Hegemonía y antagonismo: el imposible fin de lo político. Santiago de Chile: Editorial Cuarto Propio.

Lazzara, M.(2013).Aproximación al pensamiento crítico de Nelly Richard: fundamentos y debates de (y con) la crítica cultural. Taller de letras, (54), 149-158.

Machado, V. (2008). Lygia Pape, arte e urbanidade. Corpocidade - Debates em estética urbana 1. Disponible en http://www. corpocidade.dan.ufba.br/arquivos/resultado/ST2/VanessaRosaMachado.pdf

Marchart, O. (2009). La política y lo político: genealogía de una diferencia conceptual. El pensamiento político postfundacional. La diferencia política en Nancy, Lefort, Badiu y Laclau. Buenos Aires: Fondo de Cultura Económica.

Muñoz, M. A. (2006). Laclau y Rancière: algunas coordenadas para la lectura de lo político. Andamios. Revista de Investigación social, 119-144. Disponible en http://www. scielo.org. $\mathrm{mx} /$ scielo.php? pid $=\mathrm{S} 1870$ $-00632006000100005 \&$ script $=$ sci_arttext

Museos Vivos (s. f.). Juanito Laguna aprende a leer. Ministerio de Educación de la $\mathrm{Na}$ ción Argentina. Disponible en http://mu seosvivos.educ.ar/indexa317.html?p= 1100

Pequeno, F. (2013). Lygia Pape e Helio Oiticica: conversas e fricções poéticas. Rio de Janeiro: Apicuri.

Quezada, L. (2014). Nelly Richard sobre su curaduría para la Bienal de Venecia. Artishock. Revista de Arte contemporáneo. Disponible en http://www.arti shock.cl/2014/12/11/nelly-richard-sobre -su-curaduria-para-la-bienal-de-venecia/

Rancière, J. (2000). Política, identificación y subjetivación. En B. Artidi (Ed.), El reverso de la diferencia: identidad y política (pp. 145-152). Caracas: Nueva Sociedad. Rancière, J. (2002a). La división de lo sensible. Estética y Política. Salamanca: Consorcio Salamanca.

Rancière, J. (2002b). La revolución estética y sus resultados. New Left Review, 14, 118-134. Disponible en http://newleftreview.es/article/download_pdf?langua ge $=$ es\&id $=2383$

Rancière, J. (2005). Sobre politicas estéticas. Barcelona: Museud'Art Contemporani de Barcelona.

Rancière, J. (2006a). L'usage des distinctions, Failles, 2, 6-20. Disponible en http: $/ /$ mesetas.net/?q=node/19

Rancière, J. (2006b). La política de la estética. Otra Parte, 9, 1-15.

Rancière, J. (2006c). Política, policía, democracia. Santiago de Chile: Lom Ediciones.

Rancière, J. (2007a). El desacuerdo:política y filosofía. Buenos Aires: Nueva Visión. 
Rancière, J. (2007b). Estética y política: las paradojas del arte político. Arte y política. Argentina, Brasil, Chile y España. Disponible en http://www.ucm.es/info/ artepltk/textos.html

Rancière, J. (2008). Aesthetic Separation, Aesthetic Community: Scenes from the Aesthetic Regime of Art.ArtEResearch. A Journal of Ideas, Contexts and Methods, 2(1), 1-15. Disponible en http://www. artandresearch.org.uk/v2n1/ranciere. html

Rancière, J. (2010a). El espectador emancipado. Buenos Aires: Manantial.

Rancière, J. (2010b). Momentos políticos. Buenos Aires: Capital Intelectual.

Rancière, J. (2011).El malestar de la estética. Buenos Aires: Capital Intelectual.

Richard, N. (1994). La insubordinación de los signos: (cambio político, transformaciones culturales y poéticas de la crisis). Santiago de Chile: Cuarto Propio.

Richard, N. (2005). 'Arte y política'; lo político en el arte. En P. Oyarzún, N. Richard y C. Zaldívar (Eds.), Arte y Política (pp.
16-17). Santiago de Chile: Consejo Nacional de la Cultura y las Artes y Universidad Arcis.

Richard, N. (2007). Fracturas de la memoria. Arte y pensamiento crítico. Buenos Aires: Siglo xxI.

Richard, N. (2011). Lo político en el arte: arte, política e instituciones. Universidad Arcis. Disponible enhttp://hemi.nyu. edu/hemi/en/e-misferica-62/richard

Richard, N. (2013).Crítica y politica. Santiago de Chile: Palinodia.

Richard, N. (2014).Diálogos latinoamericanos en las fronteras del arte: Leonor Arfuch, Ticio Escobar, Néstor García Canclini, Andrea Giunta. Santiago de Chile: Ediciones Universidad Diego Portales.

Saúl, E. (1986). Balance con signo +. Lotty Rosenfeld. Cauce, (88), 28-29.

Yepes Muñoz, R. (2010) La política del arte: cuatro casos de arte contemporáneo en Colombia [en línea] (Tesis de posgrado). Pontificia Universidad Javeriana. Disponible enhttp://repository.javeriana. edu.co/bitstream/10554/855/1/cso36.pdf 